\title{
METAMORFOZY PLATOŃSKIEJ „METAFORY SLOŃCA” (RESPUBLICA 509B) W HETERO- I ORTODOKSYJNEJ TEOLOGII (I-III W.): GNOSTYCYZM, KLEMENS Z ALEKSANDRII I ORYGENES
}

Wpływ Platona na wczesną teologię chrześcijańską, zwłaszcza aleksandryjska, jest powszechnie przyjmowany przez badaczy antyku chrześcijańskiego. Nie wszyscy jednak zgadzają się z tym, iż platonizm przyczynił się w sposób pozytywny do refleksji nad Objawieniem. Niektórzy widzą w filozofii platońskiej źródło pierwotnych herezji, czego przykład znajdujemy zresztą już w starożytności ${ }^{1}$, inni - uznając zapożyczenia platońskie za pewien trend, jeśli nie „modę”, charakteryzującą pewne ośrodki intelektualno-kulturowe, w których tworzyli Ojcowie Kościoła - starają się w pewien sposób ograniczać doniosłość platonizmu w kształtowaniu się ortodoksyjnej doktryny chrześcijańskiej ${ }^{2}$. W niniejszym artykule ukażemy, w miarę możliwości szczegółowo, wpływ Platońskiej „metafory słońca” na hetero- i ortodoksyjną teologię pierwszych trzech wieków chrześcijaństwa. Ze względu na rozmiary

* Dr Damian Mrugalski OP - wykładowca patrologii, historii filozofii starożytnej i języka greckiego w Kolegium Filozoficzno-Teologicznym Polskiej Prowincji Dominikanów w Krakowie; e-mail: mnichop@gmail.com.

${ }^{1}$ Por. Tertullianus, De praescriptione haereticorum 7, ed. R.F. Refoulé, SCh 46, Paris 1957, 96-99, thum. E. Stanula, w: Kwintus Septymiusz Florens Tertulian, Wybór pism, PSP 5, Warszawa 1970, 45-47: „Filozofia bowiem jest źródłem wszystkich herezji. Z niej platonik Walentyn, wysnuł naukę o eonach [...]. Nasza nauka zrodziła się w portyku Salomona, który twierdził, że Boga należy szukać w prostocie serca. Niech o tym pamiętają ci, którzy głoszą jakieś stoickie, platońskie czy dialektyczne chrześcijaństwo. Po Chrystusie Jezusie nie potrzebujemy już żadnych badań, a po Jego Ewangelii żadnych dociekań!”. Negatywną opinię odnośnie do platońskich wpływów na chrześcijaństwo prezentuje również protestancki myśliciel A. von Harnack (Lehrbuch der Dogmengeschichte, vol. 1-3, Freiburg 1886-1890; Das Wesen des Christentums, Leipzig 1900), który w platonizmie widzi nie tylko źródło herezji, ale i całe chrześcijaństwo, wraz z dogmatami powstałymi po IV w. uznaje za obcy Ewangelii twór myśli greckiej.

${ }^{2}$ Przykładem może tu być opinia M.J. Edwardsa (Origen Against Plato, Oxford 2002, 1), który prowokacyjnie parafrazując pogląd teologów, iż „Aleksandria godzi się na platonizm, jak Londyn na smog", stara się wykazać, na przykładzie dzieł Orygenesa, że pojęcia filozofii greckiej weszły do doktryny chrześcijańskiej „poprzez selekcję a nie osmozę” (tamże, s. 56). W swej publikacji, Edwards nie wyklucza wpływów myśli Platona na kształtowanie się teologii chrześcijańskiej, jednakże, podkreślając oryginalność nauki zawartej w Biblii, stara się również ukazać oryginalność refleksji teologicznej, którą prowadzili myśliciele chrześcijańscy, żyjący w „środowisku platońskim”. 
tego tekstu, ograniczymy się jedynie do teologii aleksandryjskiej. Niemniej jednak, będziemy starali się wykazać, na podstawie wybranych tekstów gnostyków, Klemensa Aleksandryjskiego i Orygenesa, że dany koncept filozoficzny w równej mierze może wpływać na powstanie doktryn heretyckich, jak i w pozytywny sposób przyczyniać się do ortodoksyjnej refleksji teologicznej, a nawet stać u podstaw pierwszych chrześcijańskich dogmatów.

1. Platońska „metafora słońca”. W Państwie Platon porównuje ideę Dobra do słońca, które, choć odległe od ziemi i nie mające z nią materialnego kontaktu, jest przyczyną wielu zjawisk na niej zachodzących. Zanim przejdziemy do ukazania wpływów, jakie owa Platońska metafora wywarła na doktrynę hetero- i ortodoksyjnych pisarzy chrześcijańskich pierwszych wieków, przyjrzyjmy się najpierw samej metaforze oraz wnioskom, jakie wyprowadza $\mathrm{z}$ niej filozof ateński ${ }^{3}$. Interesujący nas tekst Platona brzmi następująco:

„Słońce - przyznasz, jak sądzę - udziela bytom widzialnym, nie tylko możliwości bycia widzianym, ale i powstawania, i wzrostu, i pożywienia, mimo że ono samo nie jest powstawaniem. [...] A zatem przyznasz także, że w przypadku bytów poznawalnych, nie tylko bycie poznawalnym od Dobra zależy,

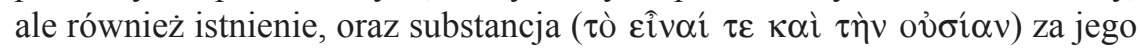
sprawą są im dane, chociaż Dobro to nie jest substancja, tylko coś ponad sub-

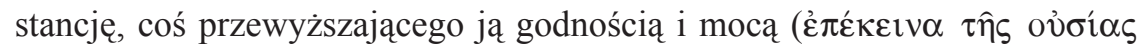

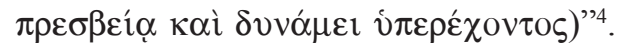

Z metafory słońca filozof ateński wyprowadza dwa podstawowe wnioski: pierwszy dotyczący epistemologii, drugi ontologii. Jeśli chodzi o pierwszy wniosek, to stwierdza on, iż idea Dobra, jest przyczyną poznawalności tego,

${ }^{3} \mathrm{~W}$ tym miejscu musimy zaznaczyć, iż w niniejszym punkcie przedstawimy to, co na piśmie, odnośnie do interesującego nas zagadnienia, stwierdził sam Platon. Pomijamy więc całe mnóstwo wypowiedzi pośrednich, które w ostatnim półwieczu stały się przedmiotem badań wielu uczonych i doprowadziły do tzw. ,nowego paradygmatu” interpretacji platońskich dialogów. Czynimy tak, nie dlatego, iż nie zgadzamy się z owym nowym paradygmatem interpretacyjnym, lecz dlatego, że w niniejszym artykule interesuje nas bardziej sposób, w jaki Platona interpretowali myśliciele wczesnochrześcijańscy. Jest prawda, że ci ostatni znali Platona zarówno bezpośrednio, z jego pism, jak i pośrednio, z przekazów innych platoników swego czasu. Celem niniejszego artykułu jest jednak ukazanie, jak pewna, bardzo nośna, metafora Platona, która niekiedy za pośrednictwem innych filozofów (zwłaszcza medioplatoników) docierała do świadomości chrześcijan, wpłynęła na refleksję teologiczną pierwszych wieków chrześcijaństwa, nie zaś śledzenie historii jej przekazu, co może być tematem odrębnej dysertacji. W kwestii nowej interpretacji Platona w świetle doktryn niespisanych odsyłamy do następujących pozycji, które zawierają także obszerniejszą bibliografię dotyczącą zagadnienia. Zob. K. Gaiser, Platons ungeschriebene Lehre, Stuttgart 1963; G. Reale, Per una nuova interpretazione di Platone alla luce delle ,dottrine non scritte”, Milano 2010; Platon. Nowa interpretacja. Materiaty z sympozjum: KUL 30 listopada - 2 grudnia 1992 r., red. A. Kijewska - E.I. Zieliński, Lublin 1993; T.A. Szlezák, Czytanie Platona, tłum. P. Domański, Warszawa 1997; tenże, O nowej interpretacji platońskich dialogów, tłum. P. Domański, Kęty 2005.

${ }^{4}$ Plato, Respublica 509b, ed. J. Adam, Cambridge 1900, 205, tłum. własne. 
co poznawalne, podobnie jak światło słońca jest przyczyną widzialności tego, co widzialne. Przedmioty poznawalne ( $\gamma(\gamma \nu \omega \sigma \kappa o ́ \mu \varepsilon v o r)$, o których mówi Platon, to oczywiście idee, które są zupełnie niecielesne, a jednak dostępne dla ludzkiego intelektu (vôิऽ) $)^{5}$ Z tego też powodu filozof określi je dalej, jako

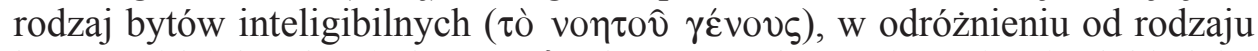

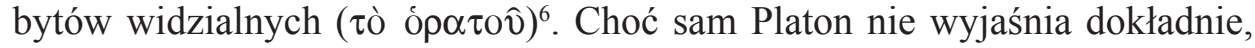
w jaki sposób się to dzieje, to jednak inteligibilność, a więc możliwość bycia poznanym, jest cechą, którą idee zawdzięczają transcendentnej względem nich idei Dobra.

Jeśli chodzi o wniosek ontologiczny, to filozof stwierdza, iż jak słońce, które istnieje ponad ziemią, sprawia, że byty materialne powstają i rozwijają

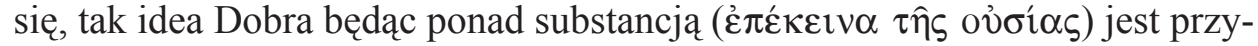
czyną istnienia jak i substancji idei. Należy tu zaznaczyć, że Platon nie mówi, iż idea Dobra jest przyczyną powstawania ( $\gamma \varepsilon \dot{v} \varepsilon \sigma 1 \varsigma)$ bytów inteligibilnych, jak to stwierdził w przypadku relacji między słońcem i bytami widzialnymi, gdyż idee są poza procesem powstawania. Są bytem realnie istniejącym, wiecznym, niezmiennym i niezniszczalnym - istnieją, lecz nigdy nie powstają ${ }^{7}$. A jednak, w jakiś sposób ich istnienie ( $\tau$ ò عîvol) i substancja ( $\dot{\eta}$ ov̉oí $\alpha$ ) zależne są od przewyższającej je godnością i mocą idei Dobra. Analogia między słońcem a ideą Dobra zarysowuje się więc następująco: tak jak słońce nie będąc po-

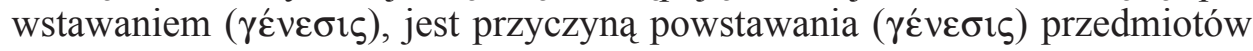
widzialnych, tak idea Dobra, nie będąc substancją (ov̉oí $\alpha$ ), jest przyczyną istnienia i substancji (ov̉oí $\alpha$ ) przedmiotów inteligibilnych, co nie oznacza, iż w tym ostatnim przypadku mamy do czynienia z przyczynowością stwórczą, czy rozciagniętą $\mathrm{w}$ czasie. Powstawanie i ginięcie nie dotyczy bowiem świata



Metafora słońca, syntetycznie ujęta w przytoczonym wyżej fragmencie Państwa (509b), jest rozwijana i wyjaśniana przez samego Platona w innych miejscach dialogu. Jej dodatkową eksplikację znajdujemy na przykład w metaforze linii ${ }^{8}$, w której filozof opisuje różne stopnie poznania dotyczące świata inteligibilnego i widzialnego. Prawdziwa wiedza ( $\dot{\varepsilon} \pi \imath \tau \eta \dot{\mu} \mu \eta)$ dotyczy więc przedmiotów matematycznych oraz idei, wraz z ideą Dobra; natomiast mniemanie ( $\delta$ ó $\xi \alpha)$, czyli poznanie niepewne, lub opinia, dotyczy przedmiotów zmysłowych i ich obrazów ${ }^{9}$. Kolejna metafora, tym razem metafora jaski-

\footnotetext{
${ }^{5}$ Por. tenże, Phaedo 65c-66a; tenże, Respublica 477a; tenże, Phaedrus $247 \mathrm{c}-\mathrm{e}$.

${ }^{6}$ Por. tenże, Respublica 509d, ed. Adam, s. 205.

${ }^{7}$ Por. tenże, Phaedo 78d-79a, ed. R.D. Archer-Hind, London 1894, 48-49, gdzie filozof, mówiąc o niezmienności i niezniszczalności idei, określa je na przemian terminami: $\mathfrak{\eta}$ ov̉oí $\alpha$ (,substancja”) oraz tò ôv („,byt”). Zob. także tenże, Phaedrus 247c, ed. W.H. Thompson, London 1868, 50, gdzie

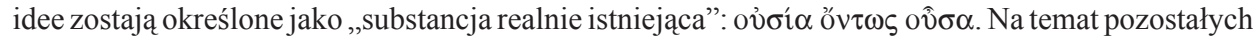
ontologicznych cech idei, wraz z licznymi odnośnikami do tekstów Platona zob. G. Reale, Historia filozofii starożytnej, II: Platon i Arystoteles, tłum. E.I. Zieliński, Lublin 2005, 91-102.

${ }^{8}$ Por. Plato, Respublica 509d-511e.

${ }^{9}$ Metafora linii, która szczegółowo opisuje różne stopnie poznania ludzkiego, zostaje poprze-
} 
ni $^{10}$, wyjaśnia w jaki sposób intelekt ludzki może dojść do oglądu idei Dobra. Otóż człowiek uwięziony w jaskini - tłumaczy Platon - który całe swe życie obserwuje jedynie cienie rzucane na jej ścianę, sądzi, iż owe cienie są realnie istniejącą rzeczywistością. Zrywając swe kajdany i odwracając się od cieni, zaczyna on widzieć przedmioty materialne, których cienie dotychczas oglądał. Owe przedmioty materialne są widzialne, gdyż oświetla je ogień rozpalony w jaskini. Odwracając się jednak od nich oraz podążając ku górze, ku prawdziwemu światłu, człowiek ostatecznie opuszcza mroczną siedzibę dotychczasowej egzystencji i zaczyna oglądać świat realny. Rzeczywistość na zewnątrz jaskini oświeca już nie ogień, lecz słońce, które początkowo wydaje się być oślepiające. Owo słońce symbolizuje oczywiście ideę Dobra, a realnie istniejące rzeczy, które ona oświetla, to nic innego jak idee należące do świata inteligibilnego.

Podobną, intelektualno-etyczną wędrówkę, która polega na odwracaniu się od tego, co cielesne i podążaniu ku rzeczywistości duchowej, albo też na wychodzeniu z ciemności do życia w świetle, będziemy mogli zaobserwować w myśli patrystycznej pierwszych wieków chrześcijaństwa. Pozostaje jednak pytanie, czy idea Dobra jest według Platona poznawalna? Odpowiedź na to pytanie pozwoli zrozumieć, jakim modyfikacjom uległa Platońska metafora W epoce patrystycznej. Wiemy już, że idee, będąc bytem realnym i niezmiennym, są według ateńskiego filozofa źródłem wiedzy prawdziwej. Idea Dobra

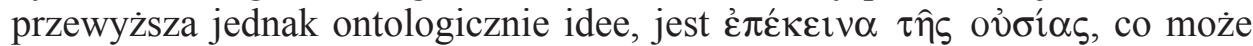
sugerować, iż jej istota nie jest uchwytna dla ludzkiego intelektu. Nie taki jednak wniosek wyprowadza Platon z metafory słońca. W niektórych jego wypowiedziach jest wprawdzie mowa o pewnych zaburzeniach wzroku człowieka, który wychodząc z jaskini zwraca się ku prawdziwemu światłu, lecz są to zaburzenia chwilowe. Filozof ateński mówi w tych miejscach raczej metaforycznie o trudzie każdego filozofa, związanym z radykalną zmianą sposobu myślenia, gdy od rozważań o bytach widzialnych zwraca swą myśl ku kontemplacji bytów świata inteligibilnego ${ }^{11}$. Celem każdego filozofa jest jednak oglądanie Dobra najwyższego i życie zgodne $\mathrm{z}$ tym Dobrem ${ }^{12}$. Zresztą cały misterny opis idealnego państwa zawiera również wskazania o kształceniu filozofów od najmłodszych lat, po to, aby przyzwyczajali się do kontemplacji Dobra,

dzona wcześniejszym wyjaśnieniem, w którym Platon dokonuje ogólnego rozróżnienia na wiedzę

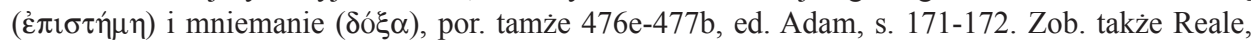
Historia filozofii starożytnej, II, s. 198-201, gdzie autor zestawia, również w przejrzystej tabeli, różne stopnie poznania zarysowane w platońskim Państwie.

${ }^{10}$ Por. Plato, Respublica 514a-518d.

${ }^{11}$ Por. tamże 515c-516d. Podobne, chwilowe zaburzenia wzroku następują także u filozofa, który przyzwyczajony do oglądania światła słonecznego, schodzi następnie do jaskini, aby tym, którzy są jeszcze uwięzieni w kajdanach, głosić naukę o prawdziwej rzeczywistości i prawdziwym słońcu, zob. tamże 516e-517a.

${ }^{12}$ Por. tamże 517b-c; 518c-519d. 
a następnie wedle tego Dobra urządzali państwo, w którym mają rządzić13 W idealnym państwie filozof musi posiadać wiedzę o Dobru najwyższym.

Kiedy więc Platon stwierdza, iż ideę Dobra trudno jest dojrzeć ${ }^{14}$, nie chce powiedzieć, iż jest to niemożliwe, lecz, że wiedzie do niej trudny dialektyczny proces $^{15}$, który symbolicznie opisuje metafora wychodzenia z jaskini. Wiedza i prawda pochodzą od Dobra i są z nim spokrewnione, a skoro tak - stwierdza Platon - również ideę Dobra należy uznać za poznawalną $(\gamma \imath \gamma \nu \omega \sigma \kappa o \mu \varepsilon ́ v \eta \eta)^{16}$. Dusza filozofa, która odwróciła się od ciemności i zwróciła ku światłu, a więc od świata zjawisk ku bytom realnym, dostrzega - jako najjaśniejszy spośród bytów - właśnie ideę Dobra. I choć początkowo jest to trudne, przyzwyczajona do światła dusza jest w stanie to widzenie wytrzymać ${ }^{17}$. Mało tego, filozof jest zobowiązany, nie tylko wytrzymywać blask Dobra, lecz także owo Dobro jasno rozgraniczać od innych bytów i nazywać ${ }^{18}$. I choć Sokrates, w Platońskich dialogach, nie ujawnia czym jest owa istota Dobra, jest przekonany, że poznanie tej istoty jest zadaniem każdego filozofa. Platońska idea Dobra jest więc nie tylko poznawalna, ale i definiowalna i wyrażalna ${ }^{19}$. Zaznaczamy to w tym miejscu, gdyż dla wielu ortodoksyjnych Ojców Kościoła, jak i dla licznych heretyków pierwszych wieków chrześcijaństwa, istota Boga, porównanego do transcendentnej idei Dobra, nie będzie mogła być przedmiotem nauki

${ }^{13}$ Por. tamże 519d-520b.

${ }^{14}$ Por. tamże 517b-c.

${ }^{15}$ Por. tamże 533a-d.

${ }^{16}$ Por. tamże 508e, ed. Adam, s. 204-205. Zob. tamże 516b; 517b-c; 518c; 532a-b, gdzie jest mowa o poznawalności idei Dobra, lub o możliwości patrzenia się w słońce, które, zgodnie z platońską metaforą, jest jej symbolem. Podobnie, jak o idei Dobra, Platon wyraża się o Demiurgu - Twórcy świata materialnego, o którym opowiada w swym Timajosie. Jego odkrycie jest trudne, a opowiadanie o Nim wszystkim jest niemożliwe, por. tenże, Timaeus 28c. Stwierdzenie to nie oznacza, iż Demiurg jest niepoznawalny, lecz, że nie każdy jest w stanie odkryć Jego istnienie i poprawnie myśleć o Jego naturze. Sam Platon bowiem wylicza następnie wiele jego cech i opisuje sposób Jego działania, jako przyczyny sprawczej wszechrzeczy. Szerzej na temat metafizycznych funkcji platońskiego Demiurga i jego relacji do idei Dobra, wraz z licznymi odnośnikami do spisanych i niespisanych nauk Platona, zob. Reale, Per una nuova interpretazione, s. 497-597.

${ }^{17}$ Por. Plato, Respublica 518c-d. Odnosząc się do tego fragmentu Państwa, a także do epistemologii wyłożonej w Filebie, Szlezák (O nowej interpretacji platońskich dialogów, s. 211) słusznie zauważa, że według Platona „stopień poznawalności danej rzeczy odpowiada stopniowi jej bytu, od zupełnej ciemności towarzyszącej niepoznawalności niebędącego do wiedzy pewnej o tym, co zawsze będące. Szereg trzech paraboli w środkowej części Państwa ilustruje tę myśl nader przejrzyście: tak jak słońce jest najlepiej widoczne w sferze zmysłowej, i tak jak część linii przyporządkowana ideom reprezentuje najjaśniejsze i najpewniejsze poznanie, tak też wydobywający się z jaskini poznaje w końcu najwyższy punkt świata idei, samo Dobro, jako «najbardziej świecące z będących

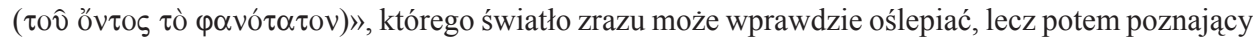
będzie w stanie je wytrzymać".

${ }^{18}$ Por. Plato, Respublica 534b-c.

${ }^{19} \mathrm{~W}$ świetle nowego paradygmatu interpretacji dialogów Platona, definicją i istotą idei Dobra jest „Jedno - Jedno, które jest absolutną miarą wszystkich rzeczy”, o którym filozof ateński pisał między innymi w swoim Parmenidesie, por. Reale, Per una nuova interpretazione, s. 361. 
i wiedzy. Światło, którym jest Bóg, jest oślepiające, i to nie jedynie chwilowo, jak to widzieliśmy u Platona, lecz w ogóle - to znaczy, że istota Boga jest niepoznawalna i niewyrażalna.

2. Gnostycyzm. Trudno jest mówić o jednolitym wpływie filozofii Platona na heterodoksyjne systemy i doktryny chrześcijańskie, które obejmujemy jednym wspólnym określeniem ,gnostycyzm”. Radykalna transcendencja Pierwszej Zasady to jednak theologoumenon gnostycki, który nie bez podstaw, możemy łączyć z Platońską tezą o transcendencji idei Dobra. Nawet jeśli w tekstach wielkich herezjologów znajdujemy informacje o tym, iż niektórzy gnostycy mówili o trzech odwiecznych Principiach ( $\alpha \rho \chi \alpha i)$ rzeczywistości, tylko jedno z nich określane jest mianem Dobra będącego przyczyną istnienia wszystkiego, co istnieje:

„Były trzy niezrodzone Zasady wszechrzeczy ( $\alpha \rho \chi \alpha i ̀ ~ \tau \hat{\omega} v$ ö $\lambda \omega v)$ : dwie męskie i jedna żeńska. Spośród dwóch Zasad męskich jedna jest nazywana Do-

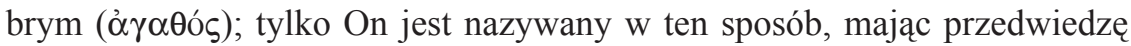

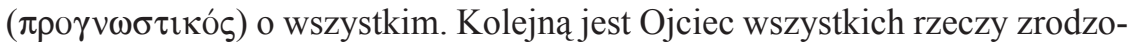
nych, nieposiadający przedwiedzy, niepoznawalny i niewidzialny (ő $\gamma v \omega \sigma \tau o \varsigma$


o podwójnym rozumie i podwójnym ciele"20.

Powyższa wypowiedź, w której Hipolit referuje poglądy Justyna Gnostyka, zawiera odwołanie do trzech Platońskich zasad rzeczywistości: idei Dobra, Demiurga i materii. Jak to jest zwyczajem gnostyków, również Justyn, łączy principia filozoficzne $z$ danymi biblijnymi. W dalszej części tekstu bowiem, Ojciec rzeczy stworzonych zostaje utożsamiony ze starotestamentalnym Elohim, a żeńska zasada z Edenem i ziemią $(\gamma \hat{\eta})^{21}$. Stwórca Elohim zapładniając ziemię (Eden) stwarza świat widzialny. Istotną jednak kwestią, i ewidentnym nawiązaniem do Platońskiej kosmologii, jest fakt, iż przed stworzeniem świata, Elohim, niczym Demiurg z Timajosa, wpatruje się w świat idealny ${ }^{22}$, a dokładniej w: „Dobro, które jest ponad wszystkim, Dobro najwyższe ( $\tau$ òv

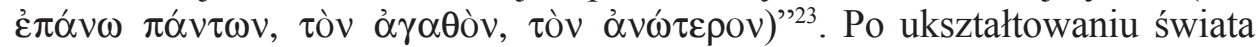

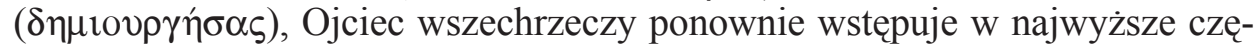
ści niebios, aby sprawdzić, czy bytom przez Niego stworzonym niczego nie

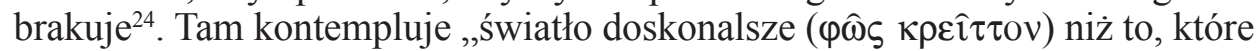
On sam stworzył"25. Chociaż Hipolit, obnażając bajkowe opowieści Justyna,

${ }^{20}$ Hippolytus Romanus, Refutatio omnium haeresium V 26, 1, ed. M. Marcovich, PTS 25, Berlin - New York 1986, 200, thum. własne.

${ }^{21}$ Por. tamże V 26, 7-14, PTS 25, 202-204.

${ }^{22}$ Por. Plato, Timaeus 29a.

${ }^{23}$ Por. Hippolytus Romanus, Refutatio omnium haeresium V 24, 1, PTS 25, 199.

${ }^{24}$ Por. tamże V 26, 14, PTS 25, 204.

${ }^{25}$ Tamże V 26, 15, PTS 25, 204, tłum. własne. 
stwierdza, iż mają one więcej wspólnego z mitologią Herodota niż z Pismem Świętym, nie trudno dostrzec w nich owej Platońskiej matrycy, na podstawie której będą zbudowane wszystkie doktryny gnostyckie. Transcendentne i jaśniejące „nadzwyczajnym” świattem Dobro, demiurgiczna aktywność Stwórcy, który z jednej strony wpatruje się „w górę”, z drugiej zaś łączy się z polimorficznym i cielesnym podłożem stworzenia, będącym przyczyną istnienia zła $\mathrm{w}$ świecie, to niewątpliwie elementy platońskiej, a nie mitologicznej teologii.

Warto w tym miejscu zwrócić jeszcze uwagę na motyw epistemologiczny doktryny Justyna Gnostyka. Pierwsza Zasada, czyli Dobro najwyższe, jest według niego, nie tylko przyczyną wiedzy, jak wyjaśniał Platon w swej metaforze słońca, lecz Ono samo, będąc ukazane w sposób spersonifikowany, ma wiedzę


dają. Zdobywają ją o tyle, o ile są w stanie wpatrywać się w źródło światła, którym jest Dobro najwyższe. W doktrynie Justyna Gnostyka wiedzę o Dobru zdobywa jedynie Stworzyciel świata, który weryfikuje swoje dzieło stworzenia w świetle zasad (idei?), które ogląda w Pierwszej Zasadzie ${ }^{26}$. On sam jednak, choć nie jest doskonały, jak Dobro najwyższe, jest niepoznawalny i nie-

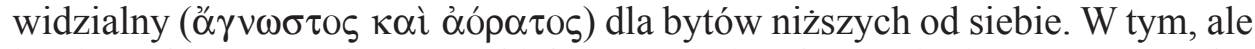
i w innych systemach gnostyckich, mamy więc do czynienia z pewną modyfikacją platońskiej metafory słońca, która polega na wprowadzeniu elementu degradacji świata duchowego, w miarę oddalania się od Prazasady. Wszystkie idee platońskie $\mathrm{w}$ równym stopniu były dobre, w równym stopniu wieczne, niezmienne, ale i poznawalne. W świecie gnostyckich eonów natomiast panuje pewna hierarchia, która dotyczy zarówno ich statusu ontologicznego, jak i epistemologicznego. Owa hierarchia, choć nie wspominał o niej Platon, jest jednak związana ze swoistą interpretacją metafory słońca. Jej symbolem staje się bowiem rozchodzące się światło, które słabnie w miarę oddalania się od swego źródła. Kolejne eony posiadają więc coraz mniejszą moc, ale i coraz mniejszą wiedzę na temat najwyższego Dobra. Wrócimy do tego tematu niżej, analizując już konkretne teksty źródłowe.

Oprócz przekazu dotyczącego myśli Justyna Gnostyka, metafory związane ze światłem znajdujemy również w świadectwach o doktrynach innych gnostyków. Ireneusz informuje, iż Otchłań (BvӨós), a więc pierwszy i transcendentny eon w systemie ofitów i setian, jest niewyczerpanym źródłem światła:

„Jest jakieś pierwsze światło (primum lumen) w mocy Bythosa, błogosławione, niezniszczalne i nieskończone, a jest nim Ojciec wszystkiego i nazywa się Pierwszym Człowiekiem. Z niego pochodzi jego Ennoia i nazywają ją synem tego, który ją wyprowadził. A więc jest to Syn Anthroposa, Drugi Człowiek. Pod tymi dwoma jest święty Duch, a poniżej Ducha, jeśli coś jeszcze

${ }^{26}$ Trudno dokładnie powiedzieć, co kontempluje Ojciec stworzenia i jaką wiedzę o Dobru najwyższym posiada. W przekazie Hipolita jest mowa jedynie o tym, iż w światłości, w której zamieszkuje Dobro, ujrzał On „to, czego oko nie widziało, ani ucho nie słyszało, ani nie weszło w serce człowieka" (1Kor 2, 9). Por. tamże V 26, 16-17, PTS 25, 204. 
pozostaje, oddzielone elementy: Woda, Ciemność, Przepaść, Chaos. Ponad nimi unosi się Duch, którego też nazywają Pierwszą Kobietą. Następnie, jak mówią, gdy Pierwszy Człowiek ze swym Synem cieszył się z piękności Ducha, to jest Kobiety, oświecił ją (illuminante eam) i zrodził z niej światło niezniszczalne (lumen incorruptibile), Trzeciego Mężczyznę, którego nazywają Chrystusem, Synem Pierwszego i Drugiego Człowieka oraz Ducha Świętego, to jest Pierwszej Kobiety"27.

W powyższym tekście rozpoczynającym opis emanacji kolejnych eonów Ireneusz odwołuje się do metafory światła, którego źródłem jest Bythos. Owo

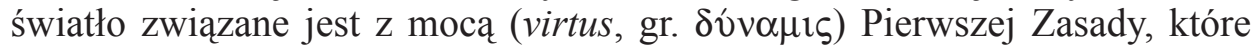
rozchodzi się, a w miarę rozchodzenia i oddalania się od Bythosa, w pewien sposób słabnie lub rozprasza się. Widać to w dalszej części Ireneuszowego tekstu. Matka żyjących, która według mitu, obcowała z Ojcem i Synem była przepełniona światłem, wręcz nim tryskała. Nie mogła jednak przyjąć i ogarnąć wielkości świateł (magnitudo luminum), które pochodziły od Pierwszej Zasady $^{28}$. Kolejni synowie Matki, jak i ich synowie, posiadają tego światła coraz mniej. ,Jak w zrodzeniu, tak i pod względem godności i sił (dignitatibus et virtutibus), jeden poprzedza drugiego"29. Pierwszy z nich, Jaldabaoth, tożsamy ze starotestamentalnym Stwórca, posiada jeszcze ową świetlaną moc, lecz wzgardziwszy Matką, i za jej pozwoleniem, wyzbywa się tej mocy. Stwarzając bowiem człowieka, przekazuje mu wraz z ,tchnieniem życia” resztki światła, które posiadał ${ }^{30}$.

Pomijając wyjaśnienia poszczególnych elementów ofickiego mitu, warty podkreślenia jest fakt, iż gnostycy wydobywają z Platońskiej metafory słońca, nie tylko koncept transcendencji Pierwszej Zasady, lecz również, podobnie zresztą jak to czynią inni myśliciele aleksandryjscy: Filon, Klemens i Orygenes $^{31}$, skupiają swą uwagę na promieniach emanowanych przez słońce i wyciagają zeń brzemienne teologicznie wnioski. Bóg, jako niewyczerpane źródło niezliczonych mocy staje się wręcz niepodważalnym dogmatem teologii aleksandryjskiej pierwszych wieków. Teologia gnostycka, o czym już wspomnieliśmy wyżej, wprowadza jednak pewien element degradacji świata duchowego, którego nie znajdziemy w teologii ortodoksyjnej. W Otchłani (Bythosie) tkwi więc nieskończona moc, której nic nie jest w stanie pojąć i ogarnąć.

${ }^{27}$ Irenaeus, Adversus haereses I 30, 1, ed. A. Rousseau - L. Doutreleau, SCh 264, Paris 1979, 364, tłum. W. Myszor: Ireneusz z Lyonu i gnostycy, Zdemaskowanie i odparcie fatszywej gnozy. Ttumaczenie: Adversus haereses. Księga I i II, SACh NS 17, Katowice 2016, 101.

${ }^{28}$ Por. tamże I 30, 2, SCh 264, 364.

${ }^{29}$ Tamże I 30, 4, SCh 264, 368, tłum. Myszor, s. 102.

${ }^{30}$ Por. tamże I 30, 5-6.

${ }^{31}$ Por. Philo Alexandrinus, Quod Deus sit immutabilis 77-81; De cherubim 97; De opificio mundi 71; De migratione Abrahami 40; De fuga et inventione 165; De mutatione nominorum 4-6. Odnośniki do odpowiednich tekstów Klemensa Aleksandryjskiego i Orygenesa znajdują się w dalszej części niniejszego artykułu, w paragrafach poświęconych omówieniu ich doktryny. 
Wychodząc z Bythosa, niczym promienie ze słońca, moc ta rozprzestrzenia się rodząc kolejne eony. Poszczególne eony przyjmują owej świetlanej mocy tyle, na ile pozwala im na to ich natura. Ponadto, moga ją przekazywać dalej, jak to ma miejsce w przypadku stworzenia człowieka, który zostaje obdarzony rozumem, będącym cząstką boskiej mocy.

Również gnoza szkoły Walentyna, którą można określić jako najbardziej intelektualny nurt gnostycyzmu ze względu na subtelność i oryginalność spekulacji oraz metod interpretacji tekstu ${ }^{32}$, pozostaje pod widocznym wpływem ontologii Platona i wykorzystuje różne elementy platońskiej metafory światła. W Liście dogmatycznym Walentynian, przekazanym przez Epifaniusza z Salaminy, eony zostają określone jako światła $(\varphi \hat{\omega} \tau \alpha)^{33}$. Emanacja zaś poszczególnych eonów, dokonuje się w wyniku połączenia, które zostaje nazwane

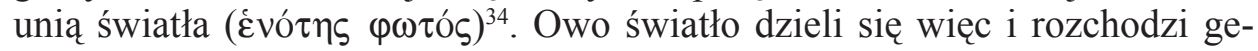
nerując kolejne eony. Choć mamy tu do czynienia z językiem materialistycznym, chodzi oczywiście o rzeczywistość absolutnie niecielesną i duchową. Jej źródłem jest transcendentny Ojciec ( $\alpha$ $\tau o \pi \alpha ́ \tau \omega \rho)$, który ,zawiera w sobie

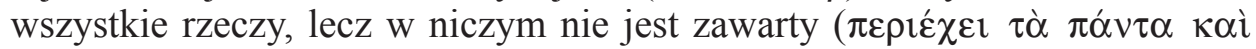

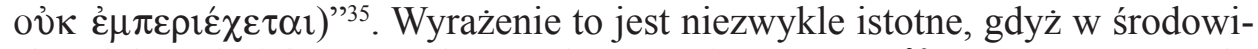
sku aleksandryjskim, u Filona, Klemensa i Orygenesa ${ }^{36}$, staje się ono technicznym określeniem wyrażającym niewyczerpaną moc twórczą, a zarazem transcendencję Pierwszej Zasady. Tak więc Bóg zhellenizowanych Żydów, ale także gnostyków i chrześcijan, jest niczym słońce, którego promienie stają się przyczyną istnienia tego, co istnieje na ziemi. Promienie te obejmują całą rzeczywistość, choć samo słońce, przez nic nie jest ogarnione: ani fizycznie, ani intelektualnie.

Choć w tekstach Walentynian, Bóg określany jest wieloma imionami, takimi jak Prazasada, Praojciec, Otchłann ${ }^{37}$, Monada $^{38}$, Ojciec wszechrzeczy ${ }^{39}$, Bóg doskonały i dobry ${ }^{40}$, zostaje nazwany również „światłem samoistnym”,

${ }^{32}$ Por. M. Simonetti, Valentino e la sua scuola, w: Testi gnostici in lingua greca e latina, a cura di M. Simonetti, Milano 2005, 201.

${ }^{33}$ Por. Epiphanius Constantiensis, Panarion 31, 6, 3-6, ed. K. Holl, GCS 25, Leipzig 1915, 393-394.

${ }^{34}$ Por. tamże 31, 5, 6, GCS 25, 391; 31, 6, 3, GCS 25, 393.

${ }^{35}$ Tamże 31, 5, 3, GCS 25, 390.

${ }^{36}$ Por. Philo Alexandrinus, De confusione linguarum 136-137; De somniis I 63-64; De migratione Abrahami 182-183; Legum allegoriae III 4-6. Odnośniki do odpowiednich tekstów Klemensa Aleksandryjskiego i Orygenesa znajdują się w dalszej części niniejszego artykułu, w paragrafach poświęconych omówieniu ich doktryny.

${ }^{37}$ Por. Irenaeus, Adversus haereses I 1, 1; Hippolytus Romanus, Refutatio omnium haeresium VI 30, 7; Epiphanius Constantiensis, Panarion 31, 10, 5; 33, 5, 7-8; 33, 6, 3-4.

${ }^{38}$ Por. Hippolytus Romanus, Refutatio omnium haeresium VI 29, 2.

${ }^{39}$ Por. Epiphanius Constantiensis, Panarion 33, 3, 7; 33, 5, 5; Hippolytus Romanus, Refutatio omnium haeresium VI 29, 3. 7.

${ }^{40}$ Por. Clemens Alexandrinus, Stromata II 114, 3-6; Epiphanius Constantiensis, Panarion 33, 7 , 5-6; Hippolytus Romanus, Refutatio omnium haeresium VI 29, 8. 
o czym informuje nas Ptolemeusz, uczeń Walentyna, w swoim Liście do Flory. Wprowadzając rozróżnienie między naturą Boga Dobrego - Ojca Jezusa Chrystusa, naturą Demiurga - Boga Stwórcy i dawcy prawa Starego Testamentu oraz naturą diabła, stwierdza:

„Istotą przeciwnika jest zniszczenie i ciemność (skoro jest on materialny $\mathrm{i}$ podzielony $\mathrm{w}$ sobie samym), natomiast istotą niezrodzonego Ojca wszystkiego jest niezniszczalność i samoistne światło, prostota i jednolitość

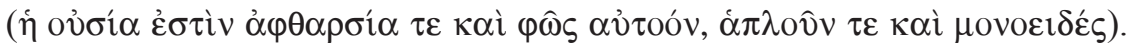
Tego zaś [tj. Demiurga] istota wyprodukowała jakąś podwójną moc, on sam natomiast jest obrazem kogoś silniejszego"41.

Ciemność należy więc do istoty (ov̉oí $\alpha$ ) przeciwnika Boga, czyli diabła. Demiurg, ponieważ jest Stwórcą świata materialnego - Stwórcą stworzonym na obraz świata duchowego - ma w sobie podwójną moc, która łączy w pewnym sensie światło i ciemność. Istotą Boga doskonałego jest natomiast światło


wyższego, oraz z wszystkich wcześniej przytaczanych fragmentów tekstów, światło, które rozchodząc się i dzieląc rodzi kolejne eony, pochodzi właśnie ze źródła, którym jest Bóg doskonały - Ojciec wszechrzeczy. Owo źródło jest niewyczerpane, nieskończone i niczym nieogarnione. $\mathrm{Z}$ tego właśnie powodu Walentynianie, jak i reprezentanci innych szkół gnostyckich, będą mówili o absolutnej niepoznawalności i niewyrażalności Pierwszej Zasady, z której wszystko pochodzi ${ }^{42}$. Bythos jest więc światłem oślepiającym, którego nie tylko człowiek, ale i poszczególne eony ogarnąć w zupełności nie mogą ${ }^{43}$. Dlatego też, choć gnostycy przypisują mu wiele nazw, żadna z nich nie wyraża tego, czym jest naprawdę. Nawet słowo „Bóg” ( $\theta \varepsilon o ́ s)$ wydaje się być nazwą niewłaściwa, $\mathrm{w}$ odniesieniu do Tego, który jest ponad wszelkim bytem i od którego przecież pochodzą inni bogowie ${ }^{44}$.

${ }^{41}$ Epiphanius Constantiensis, Panarion 33, 7, 7, GCS 25, 457, thum. M. Gilski: Epifaniusz z Salaminy, Panarion. Herezje 1-33. Tekst grecki i polski, Kraków 2015, 549.

${ }^{42} \mathrm{~W}$ tym kontekście słusznie zauważa J. Daniélou (Message évangélique et culture hellénistique aux II et III siècles, Paris 1961, 309-313), że termin ö $\gamma \nu \omega \sigma \tau o \varsigma$ (=,niepoznawalny”), staje się u gnostyków terminem technicznym w mówieniu o radykalnej transcendencji epistemologicznej Boga. Wcześniej bowiem ów termin, choć występował w wielu tekstach filozoficznych i patrystycznych, odnosił się do niepoznawalności względnej. Oznacza to, iż według licznych autorów, również według Platona, Bóg był niepoznawalny dla wielu ludzi, ze względu na trud intelektualny, który

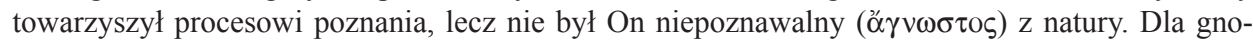
styków, niepoznawalność Pierwszej Zasady staje się niepodważalnym dogmatem. Szerzej na temat transcendencji walentyńskiego Bythosa, oraz na temat ewentualnych wpływów nauk Platona (spisanych i niespisanych) na system Walentyna zob. G. Chiapparini, Valentino gnostico e platonismo. Il valentinianesimo della „Grande Notizia” di Ireneo di Lione: Fra esegesi gnostica e filosofia medioplatonica, Milano 2012, 299-410.

${ }^{43}$ Por. Irenaeus, Adversus haereses I 2, 1; 2, 5; Clemens Alexandrinus, Excerpta ex Theodoto 29.

${ }^{44}$ „Bogowie” to również nazwa eonów wyemanowanych przez Bythos, zob. Irenaeus, Adversus

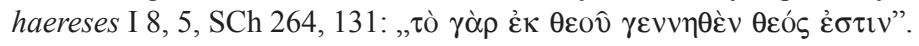


Bazylidianie, według informacji przekazanych przez Hipolita, określają nawet pierwszą Zasadę, jako: „nie-będącą-Bogiem” (ò ov̉k ஸ̂v $\theta \varepsilon o ́ s)$, właśnie ze względu na jej radykalną transcendencję ontologiczną. Na początku więc, przed jakimkolwiek stworzeniem, czy jakąkolwiek emanacją, była według nich absolutna Nicość:
„A więc - powiadają - nic nie było, ani materii, ani substancji (ov̉oí $\alpha$ ), ani

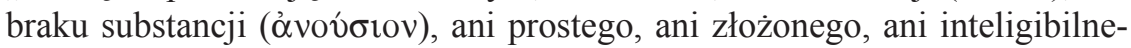 go, ani zmysłowego, ani człowieka, ani anioła, ani Boga, ani czegokolwiek z rzeczy nazywalnych lub ujmowanych zmysłami lub myślą, ani - oddając to bardziej subtelnie - jakiejkolwiek z rzeczy definiowalnych. Nie-będący-Bóg

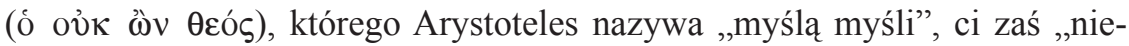 -będącym”, bez myśli, bez zmysłów, bez woli, bez zamiaru, bez namiętności, bez pożądania chciał stworzyć świat. Mówię zaś „,chciał”, jedynie, aby coś wyrazić, w rzeczywistości bowiem - bez woli, bez myśli, bez zmysłów"45.

Bóg najwyższy, o którym mowa w cytowanym tekście, nie należy do żadnej kategorii fizycznej, czy nawet metafizycznej. Nie można Go nazwać substancją (ovं $\left.\sigma^{\prime} \alpha\right)$, gdyż, podobnie jak platońska idea Dobra, jest ponad wszelką

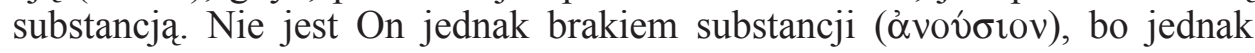
w jakiś sposób istnieje. Mało tego, jak czytamy w dalszej części tekstu Hipolita, jest On przyczyną istnienia innych substancji, które rodzą się z nasienia przezeń wyrzuconego ${ }^{46}$. Choć Bazylides, mówiąc o zrodzeniu świata duchowego, unika terminu „emanacja” ( $\pi \rho \circ \beta o \lambda \eta ́)$, ze względu na jego materialistyczne konotacje ${ }^{47}$, stwierdza, iż to, co powstało z nasienia wyrzuco-

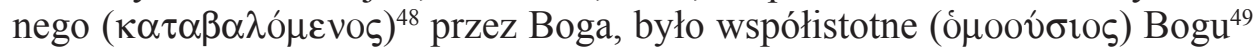
i, podobnie jak On, było „nie-istniejące" ${ }^{50}$. Terminologia negatywna używana przez Bazylidesa może więc być myląca. Jego teza, iż świat powstał z niczego

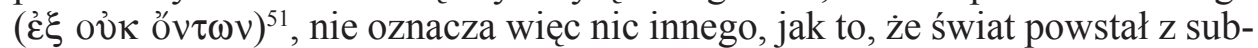

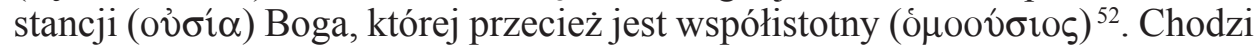
tu oczywiście o świat bytów duchowych - eonów.

\footnotetext{
${ }^{45}$ Hippolytus Romanus, Refutatio omnium haeresium VII 21, 1-2, PTS 25, 287-288, thum. własne.

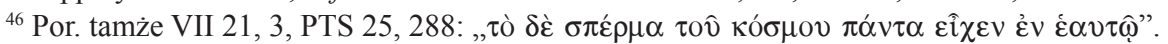

${ }^{47} \mathrm{O}$ wątpliwościach Bazylidesa odnośnie do terminu „emanacja” ( $\left.\pi \rho \circ \beta \circ \lambda \eta ́\right)$ informuje nas również Hipolit (Refutatio omnium haeresium VII 22, 2, PTS 25, 289). Jeśli bowiem - zauważa przyjmiemy doktrynę o emanacji, musielibyśmy założyć, że Bóg stwarza świat z jakiegoś podłoża materialnego ( pajęczyna, lub człowiek, który wytwarza rzeczy z materiałów takich jak brąz, drewno lub z innego podłoża materialnego.

${ }^{48}$ Por. tamże VII 21, 4-5, PTS 25, 288.

${ }^{49}$ Por. tamże VII 22, 7, PTS 25, 290.

${ }^{50}$ Por. tamże VII 21, 4, PTS 25, 288; VII 22, 3, PTS 25, 289.

${ }^{51}$ Por. tamże VII 21, 4, PTS 25, 288.

${ }^{52}$ Por. Simonetti, w: Testi gnostici, s. 442, nota 34.
} 
Po tym wyjaśnieniu, zrozumiałe staje się stwierdzenie z przytoczonego wyżej tekstu, a mianowicie, iż Bóg nie jest ,ani prostym, ani złożonym” (oủ $\chi$

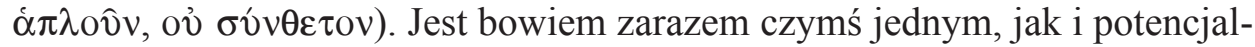
ną wielością gdyż zawiera w sobie „zalążki” świata duchowego ${ }^{53}$. Nie będąc substancja, w takim sensie, w jakim substancją są byty od Niego pochodzące, ani nie posiadając żadnej formy, która mogłaby być uchwycona w jakimś procesie poznania, wszakże nie jest ,ani inteligibilny ani poznawalny zmysło-

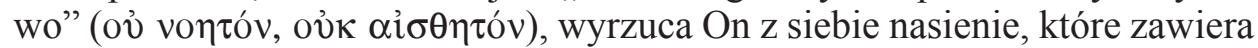

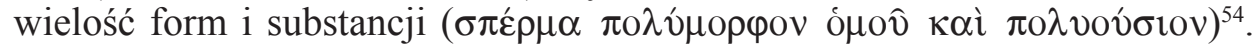
Wyliczone wyżej terminy negatywne, określające czym Bóg jest, a właściwie czym nie jest, wskazują na radykalną transcendencję epistemologiczną Boga, która jest konsekwencją Jego radykalnej transcendencji ontologicznej. W przypadku „Bytu” tak radykalnie różnego od świata, niemożliwe jest adekwatne użycie jakiegokolwiek terminu w odniesieniu do Jego natury. Nawet

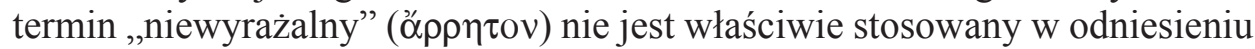
do Boga, gdyż jest on nazwą, która próbuje określić coś zupełnie nienazywalnego. O Bogu więc nie można poprawnie powiedzieć nic, nawet tego, że jest

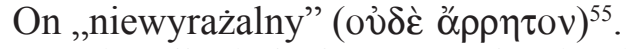

Nie tylko jednak transcendencja Pierwszej Zasady jest tym, co łączy doktrynę Bazylidesa z platońską metaforą z VI księgi Państwa. Również w tym przypadku pojawia się symboliczny język związany ze światłem pochodzącym z wysoka. Bazylidianie bowiem łączą wypowiedź z Księgi Rodzaju (1, 3): „Niechaj się stanie światłość” ze zdaniem z Janowego Prologu (1, 9): „Była światłość prawdziwa, która oświeca każdego człowieka, gdy na świat przychodzi" i stwierdzają, że ową światłością jest pierwszy eon, którego nazywają pierwszym synostwem (vió $\left.)_{5}\right)^{56}$. Mówią, iż powstał On z niczego, ale - jak już wyjaśniliśmy wyżej - owo „z niczego” odnosi się do Boga najwyższego, który nazwany jest „nie istniejącym Bogiem” (o oủk âv $\theta \varepsilon o ́ s)$. Ten, który z Niego wyszedł również zostaje określony, jako „nie-istniejący” ${ }^{57}$. Świat duchowy wywodzi się więc z Boga, niczym promienie ze słońca. Docierają one do świata materialnego, choć już nie z taką samą moca, jaką otrzymały wychodząc ze swojego źródła ${ }^{58}$. Po raz kolejny widzimy więc pewną metamorfozę

${ }^{53}$ Ową wielkość form, które znajdują się w nasieniu wyrzuconym przez Boga w momencie stworzenia świata, bazylidianie porównują do jaja, z którego rodzi się ptak, np. paw. Wielość form i kolorów, którymi charakteryzuje się dorosły osobnik, znajduje się już w zarodku jaja, choć w nim pozostaje niewidoczna. Jest to oczywiście metafora, gdyż, jak już zostało powiedziane, w przypadku zrodzenia współistotnych Bogu bytów duchowych, nie chodzi o żaden rodzaj cielesności. Por. Hippolytus Romanus, Refutatio omnium haeresium VII 21, 5.

${ }^{54}$ Tamże VII 21, 5, PTS 25, 288.

${ }_{55}^{55}$ Por. tamże VII 20, 3, PTS 25, 286.

${ }^{56}$ Por. tamże VII 22, 3-7, PTS 25, 289-290.

${ }^{57}$ Por. tamże.

${ }^{58}$ Podobnie więc jak inni gnostycy, również bazylidianie przyjmują pewien proces degradacji poszczególnych bytów (,synostw”) świata duchowego. Każdy kolejny byt duchowy, w miarę oddala- 
platońskiej metafory słońca. Nie wydobywa się z niej już tylko elementu odległości dzielącej słońce od ziemi, aby wskazać na radykalną transcendencję ontologiczną Boga, lecz wykorzystuje się także element promieni słonecznych, który Platon w swoich wyjaśnieniach pominął.

Bazylidianie mówią jednak również o oświeceniu w aspekcie epistemologicznym. Ignorancja, która panowała, nie tylko w świecie materialnym, lecz także wśród archontów i Demiurga, zostaje rozproszona za sprawą iluminacji pochodzącej ze świata duchowego współistotnego Bogu najwyższemu ${ }^{59}$. Oświecenie to nie oznacza jednak pełniej wiedzy na temat natury Pierwszej Zasady, lecz świadomości, że istnieje wyższy duchowy świat, do którego, podczas końcowej apokatastazy, powrócą dusze ludzi duchowych - pneumatyków. Ostateczna reintegracja dusz w świecie duchowym, będzie polegała na zajęciu należnego im miejsca, wyznaczonego w zależności od natury, którą każda $\mathrm{z}$ nich posiada ${ }^{60}$, nie zaś na zjednoczeniu z Bogiem najwyższym. Gdy ów powrót się dokona, zostanie usunięte $z$ dusz wybranych dążenie do osiągnięcia rzeczy niemożliwych do osiagnięcia dla poszczególnych rodzajów natur. W ten sposób, nawet przy końcowej apokatastazie, istota transcendentnego Boga, jaśniejącego na szczycie świata duchowego, pozostanie dalej nieogarniona i niewysłowiona.

Nawiązania do platońskiej metafory słońca znajdujemy również w tekstach z Nag Hammadi. Jeden z nich, Tractatus Tripartitus, zasługuje na szczególną uwagę. Jest tak nie tylko dlatego, że terminologia związana ze światłem występuje w nim w bardzo wielu miejscach, ale także dlatego, że autor Traktatu, w sposób symboliczny, lub bardziej teoretyczny, stara się oddać to, co w wersji mitologicznej wykładają przedstawiciele systemów walentyniańskich. To bowiem w Traktacie Trójdzielnym znajdujemy informację o tym, iż eony są imionami mocy jedynego i transcendentnego Boga ${ }^{61}$. Ów Bóg,

nia się od Boga najwyższego, degraduje się. W świecie materialnym owo Boże „synostwo” reprezentują „ludzie duchowi” - pneumatycy, por. Hippolytus Romanus, Refutatio omnium haeresium VII 22, 7 nn. Choć w przekazie Hipolita jest mowa jedynie ogólnie o trzech rodzajach „synostwa” Bożego, w relacji Ireneusza (Adversus haereses I 24, 3nn) o doktrynie Bazylidesa jest mowa o niezliczonej ilości emanacji. Tak więc z niezrodzonego Ojca został zrodzony Umysł (Nous), z niego zrodził się Logos i Rozumienie, z nich z kolei zrodziła się Mądrość i Moc, następnie zostają zrodzeni: moce, archonci i aniołowie. Dalej, powstają różne sfery niebios, których liczba wynosi 365. Kwestia różnic zachodzących między relacją Hipolita i Ireneusza jest trudna do rozstrzygnięcia (zob. M. Simonetti, Basilide e i basilidiani, w: Testi gnostici, s. 133-136), niemniej jednak również u Ireneusza widoczny jest pewien rodzaj degradacji bytu duchowego, powstający w miarę oddalania się od niezrodzonego Boga. Niezliczone emanacje między Bogiem a światem materialnym i ich słabnąca w miarę kolejnych zrodzeń moc, wyjaśniają w jaki sposób pojawiło się zło w świecie materialnym.

${ }^{59}$ Por. Hippolytus Romanus, Refutatio omnium haeresium VII 26, 1-10.

${ }^{60}$ Por. tamże VII 27, 7-12.

${ }^{61}$ Por. Tractatus Tripartitus 73, 8 - 73, 29, ed. H.W. Attridge, w: Nag Hammadi Codex I (The Jung Codex), NHS 22, Leiden 1985, 228, tłum. W. Myszor: Tractatus Tripartitus, w: Biblioteka z Nag Hammadi. Kodeksy I i II, SACh SN 7, Katowice 2008, 99-100: „Każdy bowiem z eonów jest imieniem jakiejś właściwości i mocy Ojca, który istnieje w wielu imionach, w jakimś zmieszaniu 
określony jako jedyny Dobry i doskonały ${ }^{62}$ jest niewyczerpanym źródłem ${ }^{63}$ niezliczonych mocy, które wywodzą się z Niego niczym światło ze źródła światła ${ }^{64}$. Pomimo nieustannego wypływu mocy, doskonały Bóg nie traci nic ze swojej istoty i pozostaje niezmienny ponad wszelkim stworzeniem, niczym słońce nieustannie oświecające ziemię. Mało tego, nie udziela On całej swojej mocy bytom od Niego pochodzącym, gdyż te nie byłyby w stanie jej przyjąć w całości; w zetknięciu z nią zostałyby unicestwione ${ }^{65}$. Ze względu na swą transcendencję ontologiczną Bóg-Dobro pozostaje zupełnie niepoznawalny i niewyrażalny. ,Jest nie do wymówienia - podkreśla autor Traktatu - i nie do nazwania, przekraczając wszelki umysł i wszelką mowę"66.

To ostatnie stwierdzenie pojawi się wielokrotnie również w ortodoksyjnej teologii aleksandryjskiej, co jest kolejnym przykładem tego, iż Ojcowie Kościoła wcale nie odrzucali z góry pewnych tez filozoficznych, którymi posługiwali się heretycy ${ }^{67}$. Wręcz przeciwnie, odwołując się do tych samych metafor i używając tego samego języka filozoficznego, budowali własną teologię, starając się przy tym pozostać wiernymi danym Objawienia. Aby tego dokonać, musieli wypracować pewne kryteria interpretacji tekstu natchnionego, które, nie wykluczając użycia narzędzi filozoficznych, prowadziły do wniosków zgodnych z całością Objawienia zawartego w księgach Starego i Nowego Testamentu ${ }^{68}$. O tym jednak powiemy szerzej w następnych akapitach.

a jednak we wzajemnych udziałach. Jest możliwe, aby mówić o nim tylko z powodu bogactwa Logosu, a także bogactwa Ojca, który wprawdzie jest imieniem jedynym, ponieważ jest on tylko jeden, jednak niezliczony w swoich właściwościach i imionach. Emanacje Pełni, które są z niego, z Istniejącego, powstały nie przez rozdzielenie wzajemne, podobnie jak to się dzieje przy oddzieleniu od tego, który je rodzi, lecz ich rodzenie przyjmuje postać rozszerzenia, jak Ojciec rozszerza siebie ku tym, których miłuje, aby ci, którzy wyszli z niego, doszli także do istnienia jak on".

${ }^{62}$ Por. tamże 53, 5-10; 61, 28-30.

${ }^{63}$ Por. tamże 60, 10-15.

${ }^{64}$ Por. tamże 62, $33-63,4$.

${ }^{65}$ Por. tamże 64, 28 - 65, 1, NHS 22, 212-214, thum. Myszor, s. 96: „Ojciec odpowiednio do swojego chwalebnego miejsca ponad (bytami) Pełni, ponieważ jest niepoznawalny i nieuchwytny, ma taką wielkość i jest tak wielki, że gdyby im wszystkim, także bardziej chwalebnym eonom, które z niego wyszły, objawił się nagle i niespodziewanie, byłyby zniszczone. Dlatego zachował swoją moc i swoją niespożytą siłę w swoim sposobie własnego istnienia”.

${ }^{66}$ Tamże 65, 1-4, NHS 22, 214, tłum. Myszor, s. 96. Wypowiedzi podkreślające niepoznawalność Boga pojawiają się w Traktacie wielokrotnie, por. tamże 54, 1 - 56, 15; 71, 35 - 73, 4.

${ }^{67}$ Przykładem takiego podejścia może być wypowiedź Orygenesa, który relacjonując opinię Celsusa na temat Boga, istniejącego ponad substancją i ponad rozumem, stwierdza: „Nie chcemy polemizować ze słusznymi stwierdzeniami, choćby autorami ich byli wrogowie naszej wiary, nie chcemy spierać się z nimi, ani zbijać słusznych poglądów" (Origenes, Contra Celsum VII 46, ed. M. Borret, SCh 150, Paris 1969, 122, thum. S. Kalinkowski: Orygenes, Przeciw Celsusowi, Warszawa 1986, 368). Do tego tematu powrócimy jeszcze w dalszej części artykułu.

${ }^{68} \mathrm{O}$ różnicach, ale i o podobieństwach, zachodzących między gnostycką i ortodoksyjną interpretacją Pism Starego i Nowego Testamentu por. M. Simonetti, Między dosłownościq a alegoria. Przyczynek do historii egzegezy patrystycznej, tłum. T. Skibiński, Myśl Teologiczna 26, Kraków 2000, 27-107. 
3. Klemens Aleksandryjski. Klemens Aleksandryjski, mimo że wielokrotnie i w wyraźny sposób przeciwstawia się różnym tezom formułowanym przez gnostyków, w swej koncepcji Boga, podobnie jak oni, pozostaje wierny platońskiej metaforze słońca, opisującej transcendencję ontologiczną Pierwszej Zasady ${ }^{69}$. Jednakże, również podobnie jak gnostycy, ową metaforę modyfikuje, tak iż niekiedy trudno jest stwierdzić, czy polemizuje on z samym Platonem, czy powtarza rozstrzygnięcia gnostyków ${ }^{70}$. W każdym razie, także według Klemensa, Bóg jest niedostępną światłością, z której wywodzi się cała rzeczywistość:

„Jeśli ktoś pojmuje Boga - bynajmniej w sposób godny, cóż bowiem mogłoby być godnego Boga?, lecz jak jest możliwe - niech myśli o wielkiej, niepojętej i pięknej światłości niedostępnej ( $\varphi \hat{\omega} \varsigma$ ỏ $\pi \rho o ́ \sigma \iota \tau o v)$, zawierającej w sobie wszelką dobrą moc, wszelką zachwycającą doskonałość, troszczącej się o wszystkie byty, współczującej, niecierpiętliwej, dobrej, wszystko wiedzącej, wszystko przewidującej, prostej, słodkiej, lśniącej, nietkniętej”’1.

Choć powyższa wypowiedź stanowi nawiązanie do tekstu z 1Tm 6, 16, o Bogu „zamieszkującym światłość niedostępną”, jej wymowa zostaje nieco zmieniona. Według Klemensa, Bóg nie tyle „zamieszkuje”, co raczej ,jest” światłością $(\varphi \hat{\omega} \varsigma)$, zgodnie z Platońską metaforą. Porównanie to - jak zauważa nasz autor - jest jednak jedynie niegodnym Boga wyobrażeniem, właśnie ze względu na radykalną transcendencję Bożej natury. Nawet określenie owej światłości jako

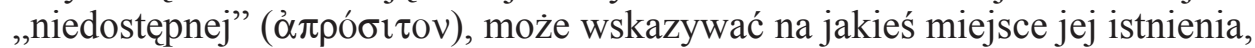
do którego nikt nie ma dostępu ( $\pi \rho \circ \sigma \imath \tau o ́ v)$, tymczasem Bóg, co zobaczymy dalej, jest ponad wszelkim miejscem i jakimkolwiek określeniem. Podobnie jak gnostycy, również Aleksandryjczyk, wydobywa z platońskiej metafory


$\dot{\alpha} \gamma \alpha \theta \eta \dot{)})$ wychodzące z Boga, działające w świecie i opatrznościowo troszczące się o każdy byt. Częściej jednak Klemens będzie mówił, nie o licznych promieniach i mocach, lecz ogólnie o jednej światłości bijącej od oślepiającego źródła światła, a więc o jednej mocy Boga, która działa na wiele sposobów W świecie. W ten sposób dokona on brzemiennego dla późniejszej teologii

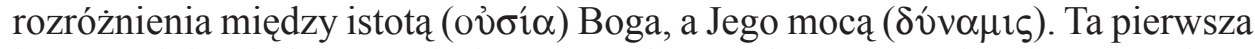
jest zupełnie niedostępna i niepoznawalna, ta druga natomiast jest sposobem

\footnotetext{
${ }^{69}$ Szerzej na temat transcendencji Boga u Klemensa pisałem w innym miejscu, por. D. Mrugalski, Il Dio trascendente nella filosofia alessandrina giudaica e cristiana. Filone e Clemente, Roma 2013, 179-311. W tej części niniejszego artykułu wykorzystam niektóre wnioski, do których tam doszedłem.

${ }^{70}$ Por. S.R.C. Lilla, Clement of Alexandria. A Study in Christian Platonism and Gnosticism, Eugene 2005, 212-226, gdzie autor zestawia liczne wypowiedzi gnostyków, medioplatoników i Klemensa Aleksandryjskiego, aby ukazać pewną wspólną matrycę, mającą swoje źródło w różnych wypowiedziach Platona, w oparciu o którą rozwijała się refleksja o Bogu transcendentnym, w środowisku aleksandryjskim II i III wieku.

${ }^{71}$ Clemens Alexandrinus, Eclogae propheticae 21, 1, ed. L. Früchtel, GCS 17, Leipzig 1909, 142, thum. własne.
} 
obecności Boga w świecie, do której ma dostęp człowiek, i na podstawie której buduje swoje wyobrażenie Boga:

„Nie należy w ogóle w odniesieniu do Ojca wszechrzeczy stosować tego rodzaju wyrażeń, jak kształt, ruch, postawa, tron, miejsce, prawa strona, lewa strona, chociaż tak pisano o Nim [...]. A więc Pierwsza Przyczyna nie ma określonego miejsca, ale istnieje ponad miejscem, czasem i nazwą, i pojęciem

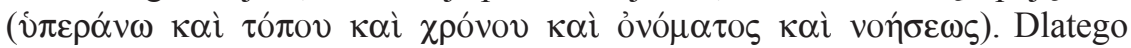
i Mojżesz mówi: «ukaż mi się sam» (Wj 33, 13), przez co w sposób jak najbardziej jasny dał do zrozumienia, że nie można ludzi pouczyć o Bogu, ani mówić

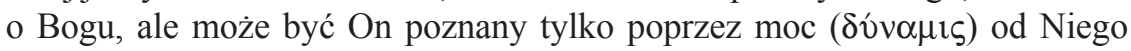

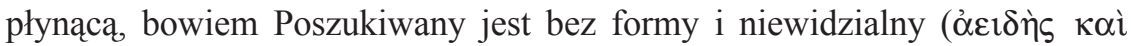

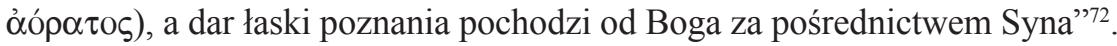

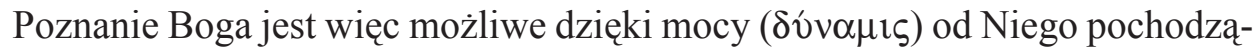
cej. Nie polega ono jednak na konceptualnym, czy definicyjnym uchwyceniu Bożej istoty, gdyż ta wymyka się wszelkim kategoriom fizycznym i metafizycznym, którymi posługuje się człowiek. Przekracza kategorię miejsca i czasu, ale także jakiekolwiek określenie (óvo $\mu \alpha$ ), czy pojęcie rozumowe (vó

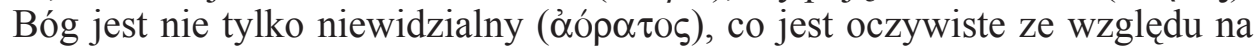
Jego niecielesność, ale także, jak podkreśla Aleksandryjczyk, zupełnie nie-

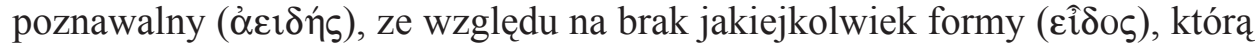
w procesie poznania uchwytuje ludzki intelekt. Choć w ostatnim zdaniu cytowanego wyżej tekstu, owa Moc, dzięki której człowiek poznaje Niepoznawalnego, zostaje utożsamiona z Synem Bożym, Klemens nie ma tu na myśli jedynie historycznego objawienia Ojca, które dokonało się za sprawą Wcielenia Logosu. Boża Moc działa bowiem w świecie od momentu jego stworzenia. Dzięki niej też Bóg stawał się bliski zawsze, dla ludzi wszystkich czasów:

„On sam, choć trzyma się z dala, jednak potrafi podejść tuż tuż. Cud to niewysłowiony! «Ja Bóg, który się zbliżam» (Jr 23, 23) - mówi Pan. Z dala pozostający wedle swej istoty (ov̉oí $\alpha$ ) - jakże bowiem mogłoby się zbliżyć coś stworzonego do Tego, który nie ma początku? - najściślej zbliża się dzię-

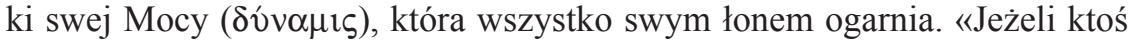
uczyni coś potajemnie - mówi Pismo - czyż nie dojrzę go również?» (Jr 23, 24) - faktycznie, zawsze jest obecna Moc Boża, która nas obejmuje swą siłą tajemniczą, dobroczynną i wychowującą. Dlatego Mojżesz, będąc przekonany, że przy pomocy samej tylko ludzkiej mądrości w żadnym wypadku poznać Boga nie można, rzekł: «Ukaż mi się sam» (Wj 33, 13) i został zmuszony wstąić w «ciemność» (por. Wj 20, 21), gdzie zagrzmiał głos Boga; to znaczy: do tajemniczych i pozbawionych kształtu przybytków myśli o bycie.

${ }^{72}$ Clemens Alexandrinus, Stromata V 71, 4-5, ed. L. Früchtel, GCS 15, Leipzig 1906, 374, tłum. J. Niemirska-Pliszczyńska: Klemens Aleksandryjski, Kobierce zapisków filozoficznych dotyczacych prawdziwej wiedzy, II, Warszawa 1994, 58-59 (thum. poprawione przez Autora). 
Bóg bowiem nie pozostaje w ciemności ani w jakimkolwiek miejscu, lecz jest ponad przestrzenią i czasem, i ponad wszelką właściwością bytów stworzonych ( Dlatego nie znajduje się nigdy w jakiejś części, jako że jest ogarniający a nie ogarniony ( $\pi \varepsilon \rho \imath \varepsilon \chi \chi \omega \nu$ o $\pi \varepsilon \rho \imath \varepsilon \chi o ́ \mu \varepsilon v o \varsigma)$, czy to przez ograniczenie, czy to przez oddzielenie" $"$ "73.

W powyższej wypowiedzi Aleksandryjczyk wyraźnie stwierdza, iż Bóg, pozostając daleki pod względem swej istoty, jest bliski pod względem swojej mocy

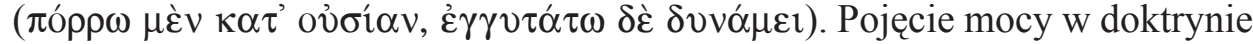
Klemensa jest jednak wieloznaczne. W poprzednim cytowanym passusie została ona utożsamiona z Synem Bożym, tym razem, interpretując alegorycznie wypowiedzi Starego Testamentu, nasz autor mówi o tajemniczej, dobroczyn-

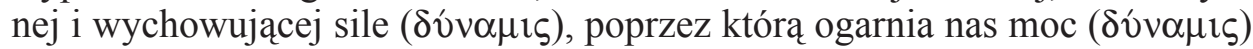
Boga. Choć tłumaczka Kobierców użyła w tym miejscu dwóch różnych słów: „siła” i „moc”, Aleksandryjczyk posługuje się jednym tylko terminem greckim: $\delta$ v́ $\alpha \mu \iota \varsigma$. Jak więc rozumieć jego wypowiedź? Otóż moc jest według Klemensa sposobem działania Boga skierowanym ku stworzeniu. Bóg w sobie to ov̉oí $\alpha$; aktywność Boga wychodząca z Jego istoty to $\delta$ v́v $\mu \iota \varsigma^{74}$. Owa moc jednak działa w świecie stworzonym na różne sposoby i to one właśnie są rozpoznawalne i uchwytywane przez ludzki intelekt. Podczas gdy sposobów Bożego działania w świecie jest wiele (stwarzanie, rządzenie, wychowywanie, zbawianie), w Bogu stanowią one jedność. Są Jego moca, a więc tym wszystkim, czym jest Bóg skierowany ku stworzeniu. Moc ma więc swoje źródło w Bogu niczym światło słoneczne w słońcu. Wychodząc zeń jednak owo światło „,rozszerza się” i ogarnia całą rzeczywistość. Dlatego też Aleksan-

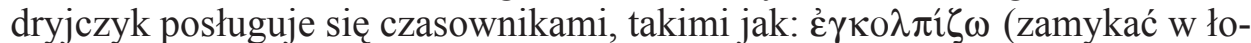
nie) i ó $\pi \tau \omega$ (związać, objąć), które wskazują na wszechogarniający charakter Bożej mocy ${ }^{75}$. Ponadto, w ostatnim zdaniu cytowanego tekstu pojawia się wy-

${ }^{73}$ Tamże II 5, 4 - 6, 3, GCS 15, 115-116, tłum. Niemirska-Pliszczyńska, I, s. 130-131 (tłum. poprawione przez Autora).

${ }^{74}$ Por. tamże VII 7, 7, ed. L. Früchtel, GCS 17, 7, gdzie Syn jest nazwany „aktywnością”, lub

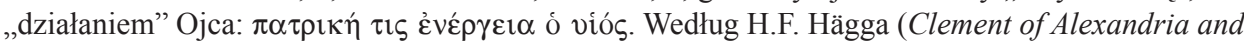

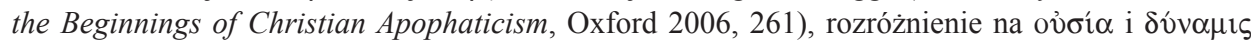
Boga, jest oryginalnym i najważniejszym wkładem Klemensa do rozwoju teologii apofatycznej. Dodajmy, że jest ono również ważne dla przezwyciężenia pewnej degradacyjnej hierarchii bytów właściwej dla systemów gnostyckich, ale także dla doktryn medioplatońskich. Według Klemensa, to nie jakieś byty pośrednie, lecz sam Bóg, dzięki swej mocy, jest obecny w świecie, objawia się i staje się poznawalny dla ludzkiego intelektu, pozostając zarazem odległym i niepoznawalnym w swej istocie. O ewentualnych podobieństwach czy też o polemice Klemensa z teologią medioplatoników w tym zakresie zob. tamże, s. 238-251.

${ }^{75}$ Warto przypomnieć w tym miejscu, cytowany już wyżej tekst z Traktatu Trójdzielnego (NHC I 73, 8 - 73, 29), w którym jest również mowa o „rozszerzaniu się” Ojca. Otóż według gnostyków emanacje powstają, nie przez oddzielenie od Bożej natury, lecz wypływają z Boga i pozostają z Nim współistotne. „Ich rodzenie przyjmuje postać rozszerzenia, jak Ojciec rozszerza siebie ku tym, któ- 
rażenie, którym posługiwali się również gnostycy, a mianowicie, że Bóg jest

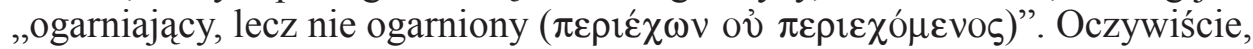
„ogarniający”, czy też „obejmujący” całą rzeczywistość dzięki mocy, która z Niego wychodzi; natomiast „nie ogarniony”, gdyż Jego istota nie może być zamknięta w żadnej stworzonej rzeczy. W rzeczywistości bowiem, pozostaje ona zawsze transcendentna względem tego, co z niej się wywodzi, na podobieństwo słońca, które oświetlając świat, nie wyczerpuje się w promieniu, choć przezeń ma wpływ na to, co istnieje w świecie ${ }^{76}$.

Ponadto, w wyżej cytowanym tekście, po raz kolejny Aleksandryjczyk stwierdza, iż Bóg jest ,ponad przestrzenią i czasem i jakąkolwiek jakością charakteryzującą byty stworzone". Te i inne wypowiedzi odsyłają nas ponownie do Platońskiej metafory słońca, przy okazji której Platon stwierdza, iż Dobro



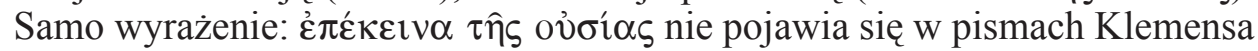
explicite, jednakże liczne inne sformułowania, które w pewien sposób sytuują Boga ,ponad” wszelkimi kategoriami metafizycznymi, jak i negatywny język, którym się posługuje nasz autor w mówieniu o Bogu, wskazują, iż Bóg - według niego - jest rzeczywiście ponad wszelkim bytem. Zostaje On na przykład nazwany Jednem, ale tuż potem dodaje Aleksandryjczyk, że jest On czymś, co

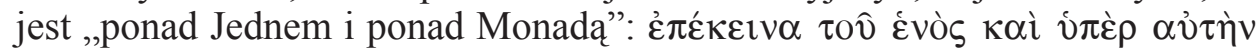
$\mu$ ovó $\delta \alpha^{77}$. Jest wprawdzie przyczyną wszystkiego, ale i czymś, co transcendu-

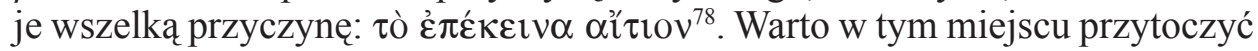

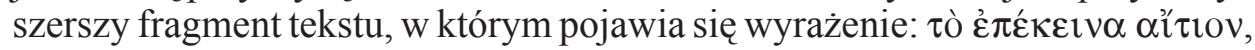

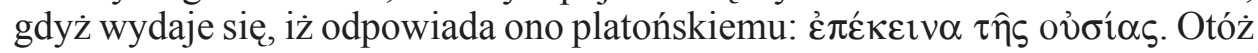
Aleksandryjczyk, opisując poszczególne stopnie wiedzy ( $\gamma \nu \hat{\omega} \sigma ı)$ ), po których wspina się doskonały chrześcijanin ( $\gamma \nu \omega \sigma \tau \imath \kappa o ́ s)$, aby oddać cześć prawdziwemu Bogu, zauważa, iż początkowo poznaje on świat widzialny, następnie studiuje Ś Swięte Księgi, a w nich najstarszą filozofię i proroków, by w końcu przejść do kontemplacji świata duchowego:

„W świecie zaś duchowym ( chodzeniem, bezczasową, nie mającą początku Zasadę ( $\tau \grave{n} v$ öxpovov

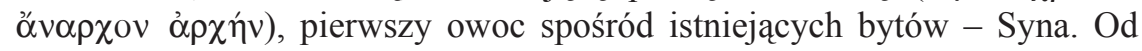
Niego można się dowiedzieć o Przyczynie ponad Przyczyną, Ojcu wszyst-

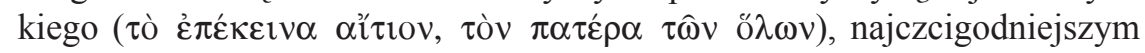

rych miłuje”. Według Klemensa Ojciec nie „rozszerza się” poprzez emanacje, lecz obejmuje wszystko swoją mocą.

${ }^{76}$ Por. Clemens Alexandrinus, Stromata VII 5, 5-6, GCS 17, 5-6, gdzie Syn zostaje nazwany „,́́wiatłem pochodzącym od Ojca”, ale także „Mocą, która przenika moce”. Również On, podobnie jak Ojciec, nie może być przez nic ogarniony ( $\mu \eta \delta \alpha \mu \hat{n} \pi \varepsilon \rho \imath \chi \chi ́ \mu \varepsilon v o \varsigma)$. Boskie światło bowiem, będąc transcendentne względem świata, rozświetla wszystko, co jest na ziemi, lecz nie ulega ani podziałowi, ani uszczupleniu, gdyż jest natury inteligibilnej.

${ }^{77}$ Tenże, Paedagogus I 71, 1, ed. O. Stählin, GCS 12, Leipzig 1905, 131.

${ }^{78}$ Tenże, Stromata VII 2, 3, GCS 17, 4. 
i najbardziej dobroczynnym dla wszystkich, o którym wiedza już nie jest przekazywana za pośrednictwem głosu, a który jest wielbiony i którego należy wielbić w sposób najwłaściwszy drżeniem i ciszą w świętym zadziwieniu"79.

Logos, który we wcześniejszych fragmentach tekstu Kobierców został utożsamiony z rządzącą wszystkim i obejmującą całą rzeczywistość

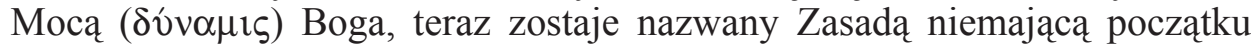

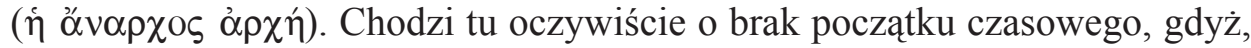

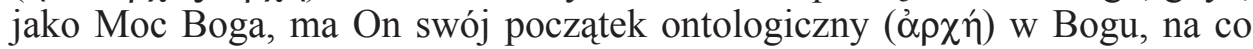
wskazują również dalsze doprecyzowania, gdzie Logos zostaje określony

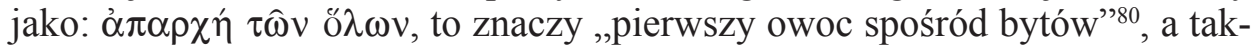

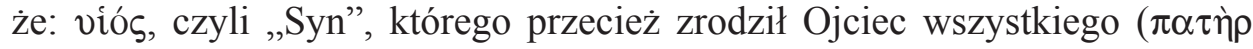
$\tau \hat{\omega} \nu$ ő $\lambda \omega v)$. Choć owa Boska Moc jest zasadą i przyczyną wszelkiego stwo-

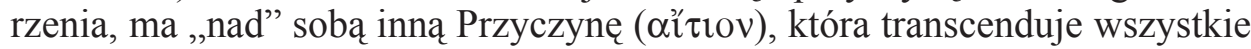
inne przyczyny. Dlatego też, Przyczyna wszystkich innych przyczyn, nawet tych transcendentnych względem stworzeń, jaką jest Logos, zostaje nazwana:

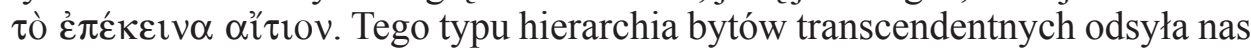
znowu do platońskiej metafory, w której przecież idee istniejące w świecie in-

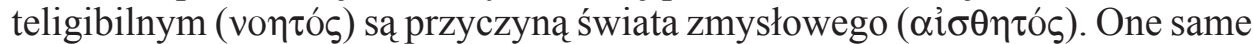
jednak, będąc bytem realnie istniejącym ( $\tau$ ò óv), lub też substancją (ov̉ $\sigma i ́ \alpha)^{81}$, choć są wieczne i niezmienne, zależą w swoim bycie od transcendentnej

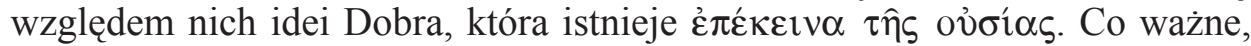
idea Dobra zostaje określona przez Platona również, jako przyczyna tego, co istnieje i co jest poznawalne, a więc idei ${ }^{82}$. Ponieważ idee $z$ kolei są przyczyną formalną bytów widzialnych, ideę Dobra można określić jako przyczynę

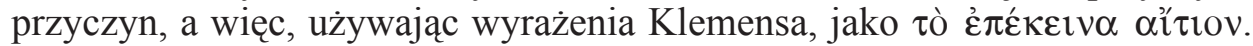
Hierarchia bytów świata inteligibilnego, jak i typowo platońska terminologia używana przez Aleksandryjczyka, nie pozostawiają wattpliwości, iż jego doktryna pozostaje pod wyraźnym wpływem filozofa z Aten i jego słynnej metafory słońca ${ }^{83}$. Opis duchowej drogi gnostyka, którego czę́́cią jest wyżej cytowany fragment, można natomiast porównać z platońską metaforą jaskini, o której opowiada Platon w VII księdze Państwa, a w której również pojawia

${ }^{79}$ Tamże VII 2, 2-3, GCS 17, 4, tłum. własne.

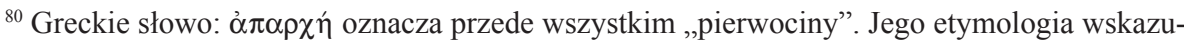

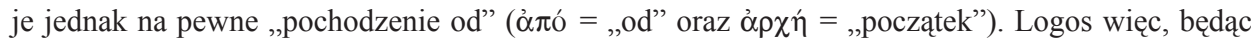
$\dot{\alpha} \pi \alpha \rho \chi \eta ் ~ \tau \hat{\omega} \nu$ ő $\lambda \omega v$, w tym sensie jest „pierwszym owocem wśród bytów istniejących”, że będąc

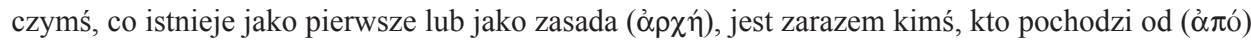
Boga. G.W. Lampe (A Patristic Greek Lexicon, Oxford 1961, 177) sugeruje nawet, iż słowo ỏ $\pi \alpha \rho \chi \eta ́$, można tłumaczyć, nie tylko jako „pierwszy”, ale i jako „najlepszy”. W tym znaczeniu Logos byłby „najwyższym” spośród bytów, gdyż jest bytem będącym przyczyną istnienia innych bytów.

${ }^{81}$ Por. Plato, Phaedo 78d-79a; tenże, Phaedrus 247c, wyżej cytowane.

${ }^{82}$ Por. tenże, Respublica 508e; $517 \mathrm{c}$.

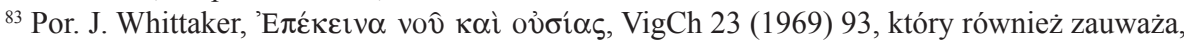

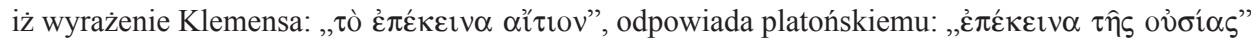
z Państwa (509b). 
się górująca nad wszystkim idea Dobra. Gnostyk więc, w zdobywaniu wiedzy, przechodzi stopniowo ze świata zmysłowego ( $\alpha i \sigma \theta \eta \tau o ́ \varsigma)$, ku poznawaniu świata inteligibilnego (voךtós), gdzie, również stopniowo, poznaje najpierw Przyczynę wszystkich bytów stworzonych, to jest Syna, a następnie Przyczynę Przyczyny, czyli Ojca. Czyni więc dokładnie to samo, co filozof, który po wyjściu z jaskini (symbolu świata zmysłowego) zaczyna stopniowo dostrzegać prawdziwie istniejące byty, oraz spoglądać na górujące nad wszystkim słońce - symbolizujące transcendentną ideę Dobra ${ }^{84}$.

Między tezami Platona a wnioskami, do których dochodzi Klemens na podstawie podobnych metafor, istnieją jednak różnice, które należy tu podkreślić. Po pierwsze, według Aleksandryjczyka, Logos, choć zawdzięcza swe istnienie transcendentnej względem niego Przyczynie, jest nie tylko przyczyną formalną, czy wzorczą świata widzialnego, ale i sprawczą. W pewnym sensie więc pełni On również rolę Demiurga z Platońskiego Timajosa. Ponadto, Syn jest jeden, podczas gdy idei istniejących w platońskim hyperuraniosie ${ }^{85}$ jest wiele. Owa wielość istnieje jednak w pewien sposób w Logosie, gdyż, jak widzieliśmy, jako Boska Moc działa On na wiele sposobów, ale i w jakimś sensie w Ojcu, gdyż idee to myśli Boga ${ }^{86}$, choć są one w Nim jednością ${ }^{87}$. Ponadto, Platon zakłada, iż idea Dobra jest poznawalna, tak jak słońce, do którego światła przyzwyczaja się filozof, po wyjściu z jaskini. Gnostyk Klemensa natomiast nigdy nie jest w stanie uchwycić istoty Boga. Słońce bowiem, podobnie jak to widzieliśmy w wielu systemach gnostyckich, jest według niego oślepiające.

Choć w wyżej cytowanym tekście, Aleksandryjczyk zauważa, iż od Syna można uzyskać wiedzę o Ojcu wszystkiego, to jednak wiedza ta, nie polega na jakimś dyskursywnym, czy definicyjnym ujęciu istoty Boga ${ }^{88}$. Nie jest więc przekazywana za pomoca głosu i, jak dalej wyjaśnia, jest to jedynie wiedza na miarę poznającego ${ }^{89}$. W innych miejscach swoich dzieł stwierdzi nawet, że ani Bóg w swojej istocie, ani Jego moc nie mogą być w pełni poznane przez człowieka, gdyż jest to rzeczywistość przewyższająca nawet świat inteligibilny:


transcendowanie tego, co jest poznawalne przez ludzki intelekt. $Z$ tego też powodu - wyjaśnia Klemens - Bóg nie może być przedmiotem nauki, gdyż ta opisuje coś, co posiada pewne formy, które mogą być uchwycone w procesie poznania, a następnie nazwane i opisane. Rzeczywistość Boska jednak, wymyka się jakiejkolwiek formie i ograniczeniu przez definicję ${ }^{91}$. Nawet nazwy,

\footnotetext{
${ }^{84}$ Por. Plato, Respublica 515c-517d.

${ }^{85}$ Por. tenże, Phaedrus $247 \mathrm{c}$.

${ }^{86}$ Por. Clemens Alexandrinus, Stromata V 73, 1 - 74, 1.

${ }^{87}$ Por. tamże V 81, 5-6.

${ }^{88}$ Por. tamże IV 156, 1; V 82, 1-4.

${ }^{89}$ Por. tamże VII 2, 3.

${ }^{90}$ Tamże V 38, 6, GCS 15, 352. Por. tamże V 65, 2; VI 165, 5 - 166, 3.

${ }^{91}$ Por. tamże IV 156, 1; V 81,5-6.
} 
które przypisuje się Bogu, czy to na podstawie danych płynących z Objawienia czy to na podstawie dyskursu filozoficznego, są według Aleksandryjczyka nazwami niewłaściwymi. Tak więc pojęcia takie jak: Jedno, Dobro, Rozum, Byt w sobie, Ojciec, Bóg, Stworzyciel, czy Pan, są czymś, czego w sposób nieudolny chwyta się ludzki intelekt pragnąc przybliżyć się do poznania Boga, w rzeczywistości jednak, opisują one jedynie różne przejawy Bożej Wszechmocy, jednakże - zauważa nasz autor - ,niczego tego rodzaju nie można zastosować do pojęcia Boga"92.

Konkludując, Dobro, które dla Platona było przedmiotem prawdziwej wiedzy ( $\dot{\varepsilon} \pi \imath \tau \eta \dot{\eta} \mu \eta)$, dla Klemensa jest absolutnie niepoznawalne i niewyrażalne, choć jeden i drugi myśliciel odwołują się do tej samej metafory słońca. Mało tego, Bóg, według Aleksandryjczyka, nie może być utożsamiony nawet z Dobrem, gdyż to oznaczałoby jakieś, choćby definicyjne, ograniczenie Jego istoty, podczas gdy On jest tym, który ogarnia wszystko, pozostając przez nic nieogarniony. Gdy jednak Klemens wspomina niekiedy o substancji, czy istocie (ov̉oía) Boga, to nie czyni tego dlatego, aby zamknąć Boga w pewnym, ściśle określonym, pojęciu metafizycznym, lecz po to, by odróżnić Boga w so-

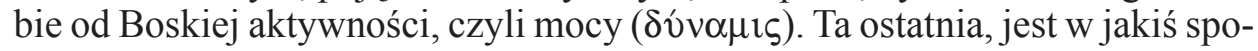
sób poznawalna, ta pierwsza w żadnej mierze. Poznawalność Boskiej mocy, związana jest z możliwością intelektualnego uchwycenia przyczyny stwórczej istniejącego świata. Bóg, źródło wszelkiej mocy, transcenduje nawet i tę przyczynę. Jest więc Przyczyną ponad Przyczyną (

4. Orygenes. Metafora słońca i światła w odniesieniu do Boga i jego Logosu pojawia się w wielu miejscach pism Adamancjusza. Dodajmy już na wstępie, że to właśnie od niej rozpoczyna Orygenes swoje analizy teologiczne w dziele $O$ zasadach. W rzeczywistości bowiem, odrzucając koncept cielesności Boga, który w jego czasach podzielali, nie tylko filozofowie, ale i niektórzy spośród chrześcijan ${ }^{93}$, teolog z Aleksandrii musi najpierw uporać się z dosłowną, tudzież materialistyczną, interpretacją metafor, którymi posługuje się Biblia w mówieniu o Bogu. Przytoczone przez niego wyrażenia: „Bóg jest duchem $(\pi v \varepsilon \hat{v} \mu \alpha)$ ” $(\mathrm{J} 4,24)$, jak i „Bóg jest ogniem ( $\pi \hat{v} \rho)$ ” (Pwt 4, 24), choć

${ }^{92}$ Tamże V 82, 2-3, GCS 15, 381, thum. Niemirska-Pliszczyńska, II, s. 66. Choć, jak słusznie zauważa Daniélou (Message évangélique, s. 302-308 i 313-316), doktryna Klemensa wykazuje duże wpływy myśli medioplatońskiej, to jednak jego koncept radykalnej transcendencji epistemologicznej Boga, stanowi epokowy przełom w historii myśli ludzkiej, gdyż teolog aleksandryjski sytuuje Boga nie tylko ponad substancją, jak to czynił Platon i platonicy, ale i ponad Dobrem samym i ponad jakimkolwiek określeniem. Moim zdaniem owo usytuowanie Boga ponad Dobrem, Jednem, Monadą, lub jakąkolwiek fizyczną, czy metafizyczną kategorią dokonało się już w myśli Filona z Aleksandrii. Szerzej na ten temat zob. Mrugalski, Il Dio trascendente, s.64-178.

${ }^{93} \mathrm{O}$ tym, iż koncept niecielesności był trudnym do zrozumienia dla wielu chrześcijan pisze Orygenes już w Przedmowie do dzieła $O$ zasadach. Zauważa on, iż termin ỏ $\sigma \omega ́ \mu \alpha \tau o \varsigma$ (niecielesny) nie pojawia się w Piśmie Świętym, oraz że Tradycja Kościoła aż do jego czasów, nie opracowała dokładnie tego zagadnienia. Por. Origenes, De principiis, Praefatio 8-9. 
pochodzenia biblijnego, pojawiają się również w tekstach stoików i oznaczają rzeczywistość cielesną ${ }^{94}$. Aby wykazać, iż autorzy Ksiąg natchnionych, posługując się tymi samymi pojęciami co stoicy, inaczej je pojmowali, Orygenes odwołuje się do jeszcze jednej biblijnej wypowiedzi: „Bóg jest światłością ( $\varphi \hat{\omega} \varsigma)$ " (1J 1, 5), która tym razem odsyła czytelnika, nie do stoickiej, lecz do platońskiej filozofii zakładającej istnienie bytów zupełnie niecielesnych. Nieprzypadkowo więc, zanim Adamancjusz zacznie analizować znaczenie biblijnych pojęć: ,duch” $(\pi v \varepsilon \hat{v} \mu \alpha)$ i ,ogień” ( $\pi \hat{v} \rho)$, przerywa niejako tok swoich wywodów skupiając się na pojęciu ,światła” ( $\varphi \hat{\omega} \varsigma)$, którym zostaje określony Bóg. Chce przez to wskazać, iż terminy używane przez autorów biblijnych obciążone są zawsze pewną interpretacja, którą nadaje czytelnik: jedne przywołują na myśl tezy stoików, inne natomiast odsyłają do Platońskiej metafory światła. Właściwe ich rozumienie nie polega jednak na odrzuceniu narzędzi filozoficznych, lecz na wnikliwym badaniu znaczeń terminów biblijnych oraz kontekstów ich występowania w całości Pisma Świętego. Taką też procedurę stosuje nasz autor podchodząc do analizy wyrażenia: „Bóg jest światłością”:

„Czymże jest światłość Boża, w której człowiek ogląda światłość, jeśli nie mocą Bożą, dzięki której oświecony człowiek ogląda prawdę wszechrzeczy albo poznaje samego Boga nazywającego się Prawdą? Taki sens ma zdanie: «W światłości Twojej ujrzymy światłość» (Ps 36, 10); znaczy to: W Słowie Twoim i w Mądrości Twojej, którą jest Twój Syn, w Tobie samym ujrzymy Ojca. Czyż bowiem dlatego, że Bóg zwie się światłością, mamy Go uważać za podobnego do światła słonecznego? Czyż można stąd powziąć choćby najlżejsze podejrzenie, iż dzięki temu materialnemu światłu może ktoś poznać przyczynę wiedzy i osiągną́ zrozumienie prawdy?"'95

W tym bardzo syntetycznym tekście, Orygenes łączy wiele wypowiedzi skrypturystycznych dotyczących światłości. Tak więc zdanie z $1 \mathrm{~J} 1,5$ zestawia ze zdaniem z Ps 36, 10, a także, czego nie widać wprost, z Prologiem Jana, gdzie jest mowa o światłości, która była w Słowie i która oświeca każdego człowieka (por. J 1, 4-9). Mając w domyśle ten ostatni fragment może bowiem stwierdzić, iż światłość, w której człowiek ogląda światłość Boga to nic innego, jak Słowo i Mądrość, a więc Syn Boży. Żadna z tych wypowiedzi biblijnych nie wspomina jednakże nic o cielesności, czy niecielesności Bożego światła. Adamancjusz przeprowadza więc własne rozumowanie w tej kwestii i zauważa, iż oświecenie oznacza poznanie prawdy, a prawda jest czymś niematerialnym, czymś, co może przysługiwać ciałom, lecz ciałem nie jest. Choć wprawdzie nasz autor wskazuje następnie na niepodobieństwo jakie zachodzi między światłem słonecznym a światłem Boga (jedno jest materialne drugie niematerialne), nie odrzuca samej metafory słońca. Podobnie jak

${ }^{94}$ Por. np.: SVF I 88; 98; 124; 146; 157; II 423; 1009; 1027; 1033; 1035; 1050; 1051; 1054.

${ }^{95}$ Origenes, De principiis I 1, 1, ed. H. Crouzel - M. Simonetti, SCh 252, Paris 1978, 90-92, tłum. S. Kalinkowski: Orygenes, O zasadach, ŹMT 1, Kraków 1996, 58-59. 
Platon, wydobywa jej epistemologiczne znaczenie: Bóg jest źródłem światła, to znaczy, że jest dla człowieka przyczyną wiedzy, jak światło słonecznie jest przyczyną widzenia rzeczy materialnych. Podobna, a nawet bardziej rozbudowaną analizę biblijnych metafor, przeprowadza Orygenes w swym Komenta$r z u$ do Ewangelii Jana ${ }^{96}$. Tam też, zgodnie z terminologią platońską, nazywa

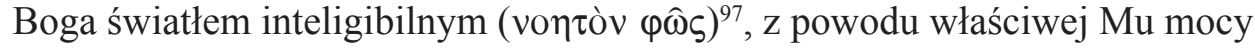



Wpływ filozofii Platona na myśl Adamancjusza jest jednak o wiele większy, aniżeli tylko pewne zapożyczenia terminologiczne. Oto bowiem, podobnie jak Platońska idea Dobra transcenduje wszelki byt, tak Ojciec, źródło światła - według filozofa z Aleksandrii - transcenduje światłość, którą jest Syn. Komentując bowiem Janowy Prolog zauważa:

„Wreszcie powiedziano, że światłość ta jest «światłością prawdziwą̨ (J 1, 9). Jak więc Ojciec Prawdy, Bóg, jest większy i doskonalszy od Prawdy, a będąc Ojcem Mądrości jest potężniejszy i doskonalszy niż Ona, tak też transcenduje

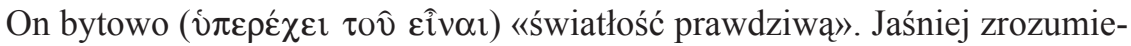
my, że Ojciec i Syn są dwiema światłościami, jeśli odwołamy się do cytatu z Dawida, który w trzydziestym piątym Psalmie powiada: «W światłości Twojej ujrzymy światłość» (Ps 36(35), 10)"999.

Badacze myśli Orygenesa dostrzegają w tym miejscu wyraźne stwierdzenia subordynacjonistyczne. Warto jednak przyjrzeć się temu, na czym dokładnie ów subordynacjonizm Syna względem Ojca polega ${ }^{100}$. Otóż Adamancjusz nie nazywa nigdy Logosu „drugim Bogiem”, jak to czynili medioplatonicy, ani

\footnotetext{
${ }^{96}$ Por. tenże, Commentarii in Joannem XIII 21, 123 - 23, 139.

${ }^{97}$ Por. tamże XIII 23, 137, ed. C. Blanc, SCh 222, Paris 1975, 104.

${ }^{98}$ Por. tamże XIII 23, 139, SCh 222, 104. Zob. Plato, Sophista 254a-b; tenże, Respublica 533d; tenże, Phaedo 65e-66a.

${ }^{99}$ Origenes, Commentarii in Joannem II 23, 151-152, ed. C. Blanc, SCh 120, Paris 1966, 306, thum. S. Kalinkowski: Orygenes, Komentarz do Ewangelii wedlug św. Jana, ŹMT 27, Kraków 2003, 116 (thum. poprawione przez Autora).

${ }^{100}$ Wielu współczesnych teologów stara się usprawiedliwiać pewne wypowiedzi Adamancjusza, które z punktu widzenia dzisiejszej teologii brzmią heretycko, poprzez wskazanie na wpływ, dominującego wówczas, ,platonizmu średniego”. Orygenes, według nich, miałby więc opisywać poszczególne hipostazy Trójcy oraz relacje między nimi zachodzące, językiem medioplatoników. Por. J. Daniélou, Orignène, Paris 1948, 85-108; E. Corsini, Introduzione, w: Origene, Commento al Vangelo di Giovanni, a cura di E. Corsini, Torino 1995, 22-41; C. Moreschini, Storia del pensiero cristiano tardo-antico, Milano 2013, 389-413. Odmienny pogląd w tej kwestii wyraża Edwards (Origen Against Plato, s. 70), który podkreślając oryginalność teologii Orygenesa, postuluje, aby nie umniejszać jej poprzez wskazywanie na pewne tendencje medioplatońskie epoki. Sam Adamancjusz bowiem z nimi otwarcie polemizował. W całej swojej publikacji, Edwards stara się jednak minimalizować rolę wpływu Platona na myśl Orygenesa. Osobiście sądzę, że należy przezwyciężyć jedną i drugą tendencję interpretacyjną. Jest bowiem prawdą, że Adamancjusz znał i odwoływał się do myśli Platona (jak i medioplatoników). Jego oryginalność polega jednak na tym, że to właśnie pogłębiona refleksja nad filozofią platońską (a nie jej odrzucenie, czy powielanie) pozwoliły mu
} 
też nie uznaje Go za jeden z eonów istniejących między Absolutem a stworzeniem, jak to czynili gnostycy. Odrzuca również adopcjonizm i modalizm ${ }^{101}$, podkreślając, iż Syn jest tej samej natury, co Ojciec ${ }^{102}$, a nawet, że jest samą substancją Boga ${ }^{103}$, choć, jako zrodzony, jest inną niż Ojciec hipostazą ${ }^{104}$. Rodzenie Syna przez Ojca jest wieczne, to znaczy, co wielokrotnie podkreśla Orygenes, nie zakłada ,jakiegokolwiek początku: ani takiego, który da się określić w czasie, ani takiego, który można sobie wyobrazić wyłącznie rozumowo"105. Owo rodzenie nie implikuje również podziału Boskiej substancji, gdyż dotyczy rzeczywistości zupełnie niecielesnej. Dlatego też porównane zostaje do pochodzenia woli z intelektu - rzeczywistości niematerialnych i ściśle ze sobą związanych ${ }^{106}$. Na czym więc polega subordynacjonizm głoszony przez Adamancjusza? W wyjaśnieniu tej kwestii pomocną staje się właśnie platońska metafora słońca. Otóż tak, jak idea Dobra jest przyczyną istnienia innych idei, wiecznych, niezmiennych i boskich, tak Ojciec jest przyczyną istnienia Syna, swej odwiecznej Mądrości. Ten bowiem, kto posiada Prawdę i Mądrość - rozumuje Orygenes - jest pierwszy logicznie, czy też ontologicznie, względem Prawdy i Mądrości, która rodzi się w Jego intelekcie. Transcendencja Ojca względem Syna, o której mowa w wyżej cytowanym fragmencie, nie odnosi się więc do przestrzeni, czasowości, czy nawet różnicy natur, lecz sposobu bytowania ( zrodzony Bóg ${ }^{107}$. Choć tekst ten mówi wprawdzie o dwóch światłach, gdyż odnosi się do dwóch różnych wypowiedzi Pisma, to w pierwszym przypadku chodzi Adamancjuszowi o źródło światła, w drugim o blask z niego pochodzący, o czym wyraźnie wspomina w innych miejscach ${ }^{108}$. W blasku, którym jest Syn, można dostrzec światło, z którego ono pochodzi, a którym jest Ojciec. Takie rozróżnienie pomaga Orygenesowi uniknąć pułapki modalizmu: Syn nie jest bowiem jedynie sposobem objawiania się Boga, lecz posiadającym tę

dojść do wielu nowatorskich rozwiązań teologicznych, co będziemy starali się pokazać w dalszej części artykułu.

${ }^{101}$ Por. Origenes, Commentarii in Joannem II 2, 16, SCh 120, 216, ŹMT 27, 86, gdzie Orygenes wykazuje błąd tych, „którzy pragną zachować pobożność, ale obawiając się, by nie wyznawać dwóch Bogów, popadają w fałszywe i bezbożne opinie: wyznają wprawdzie, że ten, którego określają mianem Syna jest Bogiem, ale nie zgadzają się, że inna jest indywidualność Syna względem indywidualności Ojca, albo wręcz przeczą bóstwu Syna i głoszą jego odrębność w indywidualności i zarazem substancji własnej względem Ojca".

${ }^{102}$ Por. tenże, De principiis I 2, 4; I 2, 8.

${ }^{103}$ Por. tamże I 2, 8.

${ }^{104}$ Por. tenże, Commentarii in Joannem I 24, 151-152; I 34, 243-245; VI 38, 188.

${ }^{105}$ Tenże, De principiis I 2, 2, SCh 252, 114, ŹMT 1, 68. Por. tamże I 2, 4; II 2,1; tenże, Commentarii in Joannem I 19, 204.

${ }^{106}$ Por. tenże, De principiis I 2, 6.

${ }^{107}$ Por. M. Simonetti, Sulla teologia trinitaria di Origene, w: tenże, Studi sulla cristologia del II e III secolo, SEA 44, Roma 1993, 118-119.

${ }^{108}$ Por. Origenes, De principiis I 2, 4, SCh 252, 118: „Est namque ita aeterna ac sempiterna generatio, sicut splendor generatur ex luce". Zob. tamże I 2, 7. 
samą boską naturę bytem, zawdzięczającym swe istnienie Przyczynie, która nie ma przyczyny.

W innym miejscu Komentarza do Ewangelii Jana znajdujemy tezę, której wydźwięk wydaje się być jeszcze bardziej subordynacjonistyczny:

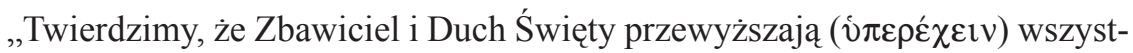
kie stworzenia, nie przez porównanie, lecz przez przekraczającą wszelką miarę wzniosłość ( szony ( $\delta \varepsilon \varepsilon \rho \varepsilon \chi o ́ \mu \varepsilon v o v)$ przez Ojca w takiej mierze, a może i bardziej, w jakiej On sam wraz z Duchem Świętym przewyższa pozostałe byty, które nie są mało znaczące. [...] Przewyższając jednakże tak wiele, tak wspaniałych bytów swą substancją, godnością, mocą, bóstwem - jest bowiem Logosem żyjącym - i mądrością, w niczym nie jest porównywalny z Ojcem. Jest bowiem obrazem Jego dobroci, odblaskiem, nie Boga, lecz Jego chwały i Jego wiecznego światła" 109.

Przystępując do analizy tego fragmentu, zwróćmy najpierw uwagę na jego drugą część. Otóż Logos przewyższa inne byty substancją i godnością, i mocą

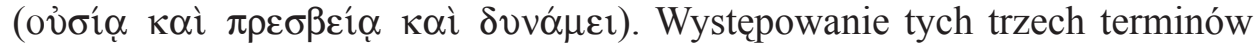
obok siebie, i to w takiej samej kolejności (nie wspominając już o czasowni-

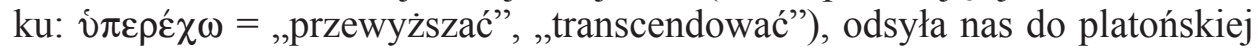
metafory z Państwa, gdzie idea Dobra zostaje określona jako: દ̇

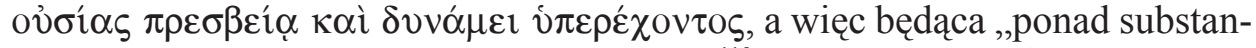
cją i przewyższająca ją godnością i mocą"110. Logos - uzupełnia Orygenes

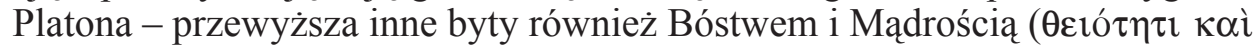
$\sigma o \varphi i ́ \alpha$ ), gdyż jest samą substancją Boga ${ }^{111}$ i substancjalnie istniejącą Mądrością Boga ${ }^{112}$. Adamancjusz, w odróżnieniu od Platona, nie stwierdza, iż Logos

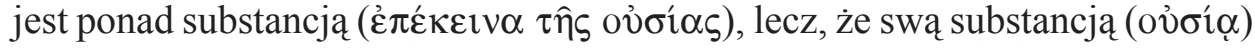
przewyższa stworzenia, które przez Niego się stały. Jest tak dlatego, iż sam Logos jest substancją - Boską substancją. W jakim sensie jednak przewyższa Go Ojciec? Otóż Ojciec nie jest w niczym porównywalny z Synem (oủ

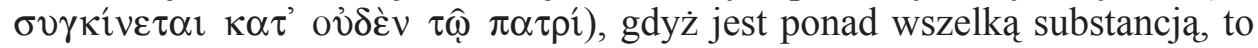
znaczy, że również substancja Syna od Niego pochodzi. Ta ostatnia teza nie zostaje wyrażona explicite, jednakże jest w pewien sposób założona. W rzeczywistości bowiem, cały wywód Adamancjusza, którego fragment został tu przytoczony, jest odpowiedzią na pytanie o naturę Boga. Nieco wcześniej bowiem Orygenes wylicza trzy opinie filozofów dotyczące natury Boga: 1) Bóg jest natury cielesnej, subtelnej i eterycznej; 2) Bóg jest niecielesny; 3) Bóg, godnością i moca, jest ponad substancją (

\footnotetext{
${ }^{109}$ Tenże, Commentarii in Joannem XIII 25, 151-153, SCh 222, 114, tłum. własne.

${ }^{110}$ Plato, Respublica 509b, ed. Adam, s. 205, thum. własne.

${ }^{111}$ Por. Origenes, De principiis I 2, 8, SCh 252, 126: „Ipsa dei substantia”.

112 Por. tamże I 2, 2, SCh 252, 112: „Unigenitum filium dei sapientiam eius esse substantialiter subsistentem".
} 


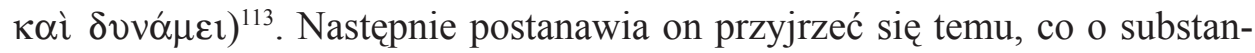
cji Boga można wywnioskować z Pism. Odpowiedź Orygenesa jest bardziej wysublimowana, niż zwyczajne: „tak” - Bóg jest substancją lub „nie” - Bóg nie jest substancją ${ }^{114}$. Cały wywód Orygenesa rozbija się o to, co znaczy być transcendentną Przyczyną wszystkiego, dalej, być niecielesną substancją zrodzoną z Boga, i w końcu być substancją stworzoną. Syn swoją substancją przewyższa substancje stworzone, gdyż jest Bogiem i Mądrością Boga: wszelka substancja stworzona zaistniała przez Niego i w Nim istnieją idee wszelkich substancji ${ }^{115}$. On sam jednak jest substancją - choć niecielesną, wieczną i Boską - to jednak substancją gdyż istnieje substancjalnie w Boskim Umyśle. Ojciec przewyższa Syna, nie dlatego, że jest Bogiem (bo i Syn jest Bogiem), lecz dlatego, że jest przyczyną istnienia substancji Syna. Syn istnieje w Nim, niczym pojęcie w intelekcie. Ojciec więc niejako „obejmuje” Syna, sam nie będąc przez nic obejmowany. Transcenduje więc wszelką substancję godno-

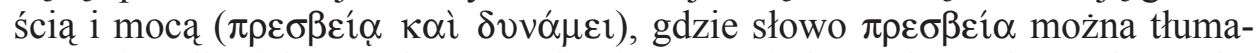
czyć nie tylko jako „godność”, gdyż i Syn posiada Boską godność, lecz jako „starszeństwo”, lub „pierwszeństwo”, nie w sensie czasowym, lecz logicznym bądź ontologicznym. Ojciec transcenduje wszelką substancję również mocą

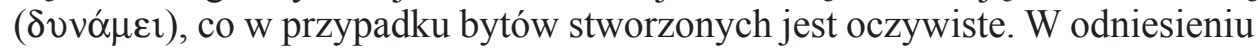
zaś do Syna, owa transcendencja polega na tym, iż wszelka moc Syna od Ojca pochodzi, co wcale nie musi oznaczać, iż jest ona mniejsza, gdyż Bóg wszystko czyni w swej odwiecznej Mądrości ${ }^{116}$, która istnieje w Nim, jak to już wyżej stwierdziliśmy, substancjalnie ${ }^{117}$. Podobne rozumowanie pojawia się również

${ }^{113}$ Por. tenże, Commentarii in Joannem XIII 21, 123, SCh 222, 94-96.

${ }^{114}$ Szerzej na temat pojęcia substancji u Orygenesa por. H. Pietras, Pojęcie Bożej substancji w poczatkach Kościoła, w: Metafizyka i teologia, red. R.J. Woźniak, Myśl Teologiczna 62, Kraków 2008, 122-140. W artykule tym Autor zestawia stoickie i platońskie rozumienie substancji. Czyni to na przykładzie pism Tertuliana i Orygenesa. Pomija jednak wątki arystotelesowskie, z którymi, jak pokażemy poniżej, również mógł polemizować Adamancjusz. Ponadto, choć Pietras przytacza teksty Orygenesa, w których jest mowa o tym, że Bóg jest ponad substancją, ostateczną konkluzją jego artykułu jest teza, że według Orygenesa, w odróżnieniu od Plotyna, Bóg jest substancją (zob. tamże, s. 140). Analizy terminologiczne, których podjął się Pietras są trafne i godne uwagi, niemniej jednak nie zgadzam się z jego ostatnią tezą. Według mnie, Orygenes kontynuuje myśl swoich poprzedników: Filona i Klemensa i choć posługuje się terminem ov̉oía („substancja”) w odniesieniu do Boga, o wiele bardziej niuansuje sprawę, co pokażemy poniżej.

${ }^{115}$ Por. tamże I 19, 111-115; I 34, 243-246; II 18, 126.

116 Por. tamże I 34 243-246; II 12, 90; VI 38, 188; XIII 36, 229-234; tenże, De principiis I 2 , 2-3; I 2, 6; I 2, 9 . W innym miejscu Adamancjusz (De principiis I 2, 10, SCh 252, 134, ŹMT 1, 76) stwierdza, iż Syn jest tak samo wszechmocny (omnipotens), jak wszechmocny jest Ojciec, gdyż „wszystko co należy do Ojca, jest również własnością Chrystusa”.

${ }^{117}$ Również w tekście, w którym Orygenes komentuje słowa Ewangelii: „Nikt nie jest dobry, tylko jeden Bóg Ojciec” (Mk 10, 18), stwierdza, że zdanie to wskazuje fakt, iż „Syn nie ma innej dobroci, lecz tę samą, którą ma Ojciec (filius non esse alterius bonitatis, sed illius solius, quae in patre est); słusznie też nazywa się jej «obrazem», ponieważ pochodzi z pierwotnej dobroci (ex ipsa principali bonitate), a nie ma w Nim innej dobroci poza dobrocią Ojca oraz nie istnieje w Synu 
w Contra Celsum, gdzie Orygenes sugeruje, iż odpowiedź na pytanie, czy Bóg jest substancją, czy też istnieje ponad nią, zależy od tego, jak pojmujemy termin substancja (ov̉ó́ $\alpha$ ):

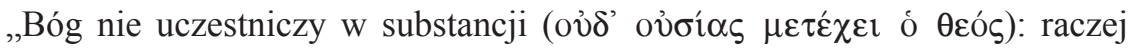
substancja uczestniczy w Bogu aniżeli Bóg w substancji; uczestniczą w Bogu ci, którzy posiadają Ducha Bożego. Podobnie, nasz Zbawiciel nie uczestniczy w sprawiedliwości, ale ponieważ sam jest sprawiedliwością, ludzie sprawiedliwi uczestniczą w Nim. Zresztą nauka o substancji jest obszerna i skomplikowana, zwłaszcza zagadnienie, czy substancja trwała i bezcielesna jest substancją we właściwym znaczeniu tego słowa; czy Bóg będąc ponad sub-

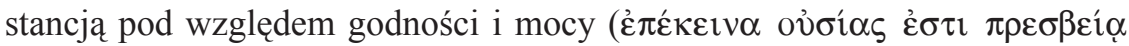

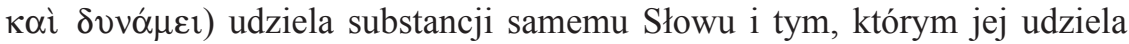
wedle Słowa, czy też sam jest substancją [...]. Należałoby się poza tym zastanowić, czy można nazywać Jednorodzonego i Pierworodnego wszelkiego

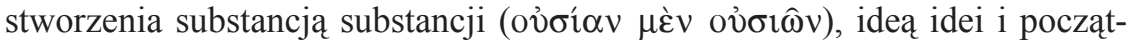

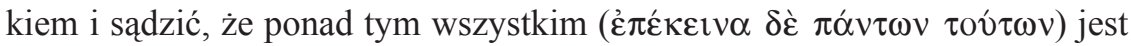
Bóg, Jego Ojciec" "118.
\end{abstract}

Choć w dziełach Orygenesa moglibyśmy wskazać jeszcze wiele innych tekstów, w których szala odpowiedzi na pytanie, czy Bóg jest substancja, czy też ponad substancją, przechylałaby się raz $\mathrm{w}$ jednym, raz $\mathrm{w}$ drugim kierunku ${ }^{119}$, to powyższy fragment jasno ukazuje stanowisko Adamancjusza w tej kwestii. Jeśli więc - wyjaśnia nasz autor - uznamy, iż byt niecielesny i transcendentny,

jakiekolwiek niepodobieństwo ani odmienność od dobroci (neque aliqua dissimilitudo aut distantia bonitatis in filio est)" (tenże, De principiis I 2, 13, SCh 252, 140-142, tłum. Kalinkowski, s. 78-79). Adamancjusz stwierdza wprawdzie w tym miejscu, że „Ojciec jest dobrocią pierwotną, co może sugerować subordynacjonizm Syna względem Ojca, lecz zaraz dodaje, że nie należy takiego stwierdzenia uważać za bluźnierstwo, „bo nie chodzi tu o to, by przeczyć dobroci Chrystusa albo Ducha Świętego; przeciwnie, należy uważać, jak to już poprzednio stwierdziłem, że pierwotna dobroć tkwi w Bogu Ojcu i że Syn, który się z Niego narodził, oraz Duch Święty, który od Niego pochodzi, niewątpliwie mają w sobie istotę dobroci istniejącej w źródle (sine dubio bonitatis eius naturam in se referet, quae est in eo fonte), z którego narodził się Syn i z którego pochodzi Duch Święty. Jeśli zaś Pismo Święte mówi o jakichś innych «dobrach», takich jak anioł, człowiek, niewolnik, skarb, dobre serce albo dobre drzewo, to mówi to przenośnie, jako o bytach, które zawierają w sobie dobroć udzieloną przypadkowo, a nie dobroć substancjalną (accidentem, non substantialem in se continentia bonitatem)" (tamże).

118 Origenes, Contra Celsum VI 64, ed. M. Borret, SCh 147, Paris 1969, 338-340, thum. Kalinkowski, 328 (tłum. poprawione przez Autora).

${ }^{119}$ Wydaje się bowiem, że Orygenes w zależności od kontekstu swojej wypowiedzi, kładzie nacisk na to, iż Bóg jest substancją prawdziwą wówczas, gdy stara się odrzucić rozpowszechniony w jego czasach pogląd o cielesności Boga. Wówczas, podkreśla on, iż Bóg, choć niecielesny, jest substancją prawdziwą i dostępną dla ludzkiego rozumu, por. tenże, De principiis I 1, 6-8. W innym zaś miejscu, podkreślając, iż Bóg jest absolutną przyczyną wszystkiego - również Syna - nie waha się stwierdzić, w duchu platońskim, iż Bóg jest ponad substancją. Robi to wówczas, kiedy prowadzi dia$\log$ z platonikami, których nie trzeba przekonywać, że byt niecielesny jest bytem realnie istniejącym. 
który istnieje samoistnie, jest substancją we właściwym tego słowa znaczeniu, to Bóg jest substancją prawdziwą, a wszystko inne na różny sposób uczestniczy w tej substancji. Tak, jak ludzie sprawiedliwi uczestniczą w Sprawiedliwości, którą jest Syn, tak ci, którzy posiadają Ducha Boga uczestniczą w substancji Boga ${ }^{120}$. Jeśli jednak uznamy, że substancją jest konkretny, określony byt, a więc coś, co jest objęte przez jakąś formę, jak np. konkretne ciało, czy nawet idea (gdyż każda idea, choć ogólna, jest ściśle określona), to Bóg nie jest substancją, ponieważ nic Go nie ogranicza, ani objąć nie może. Nie posiadając żadnych atrybutów, czy określających Go przymiotów ${ }^{121}$, transcenduje wszelki konkretny i ograniczony przez swą formę byt, zwany substancją. W innym miejscu Orygenes powie nawet, podobnie zresztąjak wcześniej gnostycy i Klemens Aleksandryjski, iż Bóg jest ogarniającym wszystko, lecz nieogarnionym

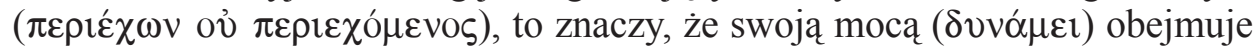
wszelką substancję: widzialną i niewidzialną̨ ${ }^{122}$, sam zaś nie może być w przez

${ }^{120} \mathrm{~W}$ dziele $O$ modlitwie Adamancjusz stwierdza to, co w powyższym tekście (tenże, Contra Celsum VI 64) jest założone: „Ci słusznie pojmują substancję (ov̉ $\sigma i ́ \alpha$ ), którzy uznają, że jest nią,


Eîvol)" (tenże, De oratione 27, 8, ed. P. Koetschau, GCS 3, Leipzig 1899, 367, thum. własne). W wypowiedzi tej, Orygenes polemizuje z tezą Arystotelesa, według którego substancją pierwszą są konkretne byty materialne, jak np. człowiek, czy koń; w drugim zaś znaczeniu substancjami są gatunki, do których substancje pierwsze należą. Por. Aristoteles, Categoriae 2a. Według Arystotelesa, gdyby nie istniały substancje pierwsze, nie mogłyby istnieć inne rzeczy (zob. tamże $2 b$ ). Nie przyjmuje on bowiem samodzielnego istnienia bytów niecielesnych. Zakłada wprawdzie istnienie pierwszego nieporuszonego Poruszyciela - czystej formy i czystego aktu - jednakże nie przypisuje $\mathrm{Mu}$ funkcji stwórczej. Nieporuszony Poruszyciel jest jedynie teoretycznym gwarantem istnienia ruchu w świecie. Orygenes widzi sprawę inaczej, to znaczy po platońsku. Substancją w pierwszym i najbardziej pierwotnym stopniu są byty niecielesne - tylko one bowiem nie ulegają powiększeniu, czy pomniejszeniu. Będąc niezmienne, wieczne i istniejące realnie są substancją prawdziwa, por. Origenes, De oratione 27, 8. Taką niezmienną i niecielesną substancją jest również Bóg, który będąc Stworzycielem, udziela istnienia innym substancjom, które Arystoteles nazywa substancjami pierwszymi. Dla Orygenesa pierwszym jest to, w czym wszystko inne uczestniczy. W tym sensie, Bóg jest substancją pierwszą, choć nie w arystotelesowskim rozumieniu tego terminu. Nie jest On wprawdzie bytem konkretnym (złożonym z formy i materii), jakby chciał Arystoteles, lecz niezmienna, wieczną i realnie istniejącą naturą niecielesną.

${ }^{121}$ Por. Origenes, De principiis I 1, 6, SCh 252, 100, tłum. Kalinkowski, s. 62: „Jest On niezłożoną istotą duchową, w której nie ma żadnych dodatkowych atrybutów; wskutek tego nie można wierzyć, iż tkwią w Nim jakieś wyższe i niższe przymioty, lecz jest Monadą, i że się tak wyrażę, Jednią jest Rozumem i Źródłem, z którego biorą początek wszystkie istoty duchowe i wszelki rozum [...]. Idzie o to, aby się nie okazało, iż to, co stanowi początek wszechrzeczy, jest złożone i różnorodne oraz że jest wielością, a nie jednością; jedność zaś, pozbawiona wszelkiej cielesnej domieszki, powinna się składać wyłącznie, że się tak wyrażę, z idei Bóstwa”.

${ }^{122}$ Por. tenże, De oratione 23, 1, GCS 3, 349-350, tłum. własne: „Należy wierzyć, że dzięki niewysłowionej mocy Jego Boskiej natury, wszystko zostało przez Niego ogarnięte i objęte

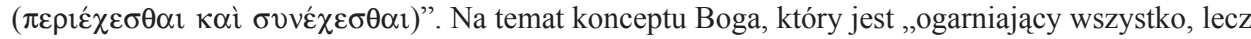
nieogarniony ( $\pi \varepsilon \rho t \varepsilon ́ \chi \omega \nu$ ov̉ $\pi \varepsilon \rho \imath \varepsilon \chi o ́ \mu \varepsilon v o \varsigma) "$, oraz stoickich korzeni tej tezy, którą jednak Orygenes przenosi na poziom bytu niecielesnego, zob. tenże, Contra Celsum VI 71; VII 34. W świetle tych 
nic objęty, czy ogarniony. Jest tak, nie tylko dlatego, że jest On niecielesny, bo i idea, choć niecielesna może być objęta intelektualnie, ale dlatego że nie ma żadnej mocy i żadnego intelektu, który by Go obejmował. Substancja, także ta niecielesna, rozumiana jako pewne określenie, może istnieć w Nim i przez Niego. Jeśli więc substancją jest to, co jest objęte przez jakąś formę, lub co jest forma, która daje się objąć, to Bóg transcenduje wszelką substancję.

$\mathrm{Z}$ powyższych analiz wynika jasno, iż Orygenes, inaczej niż Platon, pojmuje zagadnienie transcendencji - stąd też wynikają jego wahania w określeniu Boga, jako istniejącego ponad substancją. Według Platona, idea Dobra transcendowała pozostałe idee $\mathrm{w}$ tym sensie, że idee zawdzięczały jej swoje istnienie $\mathrm{i}$ wszystkie były dobre, to znaczy - wszystkie partycypowały w Dobru. Według Orygenesa, idee to myśli Boga. Bóg więc ogarnia je swoim Intelektem. Jeśli za substancję uzna się coś, co realnie istnieje, co udziela bytu innym substancjom i w czym inne substancje uczestnicza, Orygenes nie widzi powodu, w odróżnieniu od Platona, aby Boga nie nazywać substancją. Mało tego, niekiedy zależy mu nawet na tym, ze względu na tych, którzy podzielają pogląd o Jego cielesności i nie rozumieją, że byt niematerialny może być substancją prawdziwą. Sam Syn zresztą, zostaje nazwany przez Adamancju-

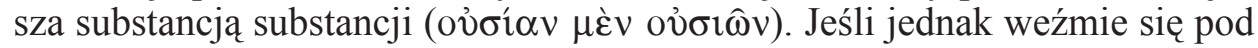
uwagę koncept substancji, jako czegoś określonego, czyli objętego przez jakąś formę, jak substancja pierwsza Arystotelesa, to - według Orygenesa - Ojciec,

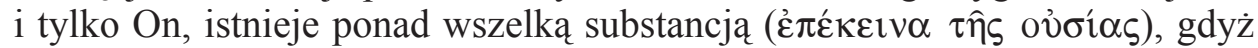
swoją mocą ogarnia wszystko, byty widzialne i niewidzialne, sam nie będąc przez nic ogarnionym ${ }^{123}$.

wypowiedzi Bóg obejmuje wszystko, również Mądrość, która z kolei obejmuje w sobie wszystkie formy i zasady związane z prawami wszechrzeczy. Zob. tenże, De principiis I 2, 9; Commentarii in Joannem I 33, 242 - 34, 244; V 5, 1.

${ }^{123}$ Nie zgadzam się z Corsinim (Introduzione, s. 37-38), który uważa, iż Orygenes nie posunął się do przypisania Bogu transcendencji względem bytu (ov̉oí $\alpha$ ), ze względu na gnostycyzm, od którego tez starał się odżegnać. Ten ostatni bowiem postulował radykalną niepoznawalność i niewyrażalność najwyższego Boga do tego stopnia, że odróżniał Go od Boga Starego Testamentu. Według włoskiego badacza, Orygenes wykorzystuje więc filozofię medioplatońską swojego czasu jedynie wówczas, gdy służy mu ona do walki z herezją. Gdy zaś sami filozofowie nie są zgodni na temat tego, czy Bóg jest bytem prawdziwym, czy też istnieje ponad bytem, również i Adamancjusz wyraża swe wątpliwości w tej kwestii. W mojej opinii, czego dowodziłem powyżej, Orygenes, zanim udzieli swej odpowiedzi na pytanie o radykalną transcendencję ontologiczną Boga, przygląda się znaczeniom pojęć i stwierdza, że w danym rozumieniu terminu ov̉ $\sigma^{\prime} \alpha$, Bóg jest substancją, w innym rozumieniu, Bóg jest ponad substancją. Orygenes nie używa więc filozofii jedynie do walki z herezją, ani też nie powtarza jedynie tego, co o Bogu twierdzili filozofowie jego epoki. Znając jednak historię danej idei, jak i różne jej rozumienia, stara się wyjaśnić swoim czytelnikom, że w pewnych twierdzeniach filozoficznych może tkwić zarazem prawda i fałsz. O takim właśnie podejściu Mistrza z Aleksandrii pisze szeroko jego uczeń Grzegorz Cudotwórca w swej Mowie pochwalnej na cześć Orygenesa. Zauważa on bowiem, iż Orygenes bardzo skrupulatnie wychwytywał fałsz w pewnych twierdzeniach filozoficznych, które jego uczniom wydawały się oczywiste i prawdziwe. Z drugiej strony, tezy, które słuchacze uznawali za fałszywe, wyjaśniał w taki sposób, że można było dostrzec 
Te subtelne rozróżnienia, które wydobywamy z wypowiedzi Adamancjusza rozsianych w różnych jego dziełach, dotyczą jednakowoż kwestii pozna-

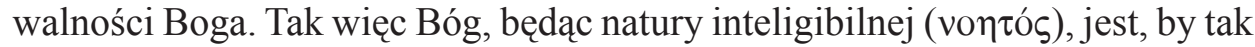
rzec: ,z natury”, poznawalny dla ludzkiego rozumu (vov̂s), który został stworzony na obraz Rozumu Boskiego ${ }^{124}$. Daje się poznać człowiekowi, poprzez objawienie naturalne, gdyż jest obecny w świecie dzięki swej mocy, która nim rządzi i podtrzymuje $\mathrm{w}$ istnieniu, ale i poprzez objawienie nadnaturalne, które dokonywało się w historii ludu Starego i Nowego Przymierza. Powyższe tezy nie muszą jednak stać w sprzeczności ze stwierdzeniem, że Bóg w swojej istocie pozostaje niepoznawalny. W wyjaśnieniu tej kwestii Orygenes również posługuje się metaforą słońca i światła:

„Jego istoty [tj. Boga] nie może przecież zrozumieć ani wyobrazić sobie (intendi atque itueri) ludzki umysł, choćby był najczystszy i najjaśniejszy. Sądzę, że nie będzie rzeczą niestosowną, jeśli dla wyraźniejszego wyjaśnienia tego zagadnienia powołamy się jeszcze na inny przykład. Otóż zdarza się, że nasze oczy nie mogą dostrzec samej istoty światła, czyli substancji słońca; oglądając jednak jego blask lub przenikające przez okno albo przez jakieś szpary promienie, możemy dzięki nim domyślać się, jakie jest źródło i pochodzenie materialnego światła. Tak zatem dzieła Opatrzności Bożej i kunsztowna budowa wszechświata $\mathrm{w}$ zestawieniu $\mathrm{z}$ samą istotą Boga i Jego naturą (ipsius substantiae eius ac naturae) są jak gdyby jakimiś promieniami Bożej natury. Ponieważ więc umysł nasz sam przez się nie może oglądać Boga w Jego naturalnej postaci, to na podstawie piękności Jego dzieł i wspaniałości stworzeń pojmuje Go jako Ojca wszechświata"125.

Po raz kolejny, jak w przypadku transcendencji ontologicznej Boga, moglibyśmy wskazać na wiele wypowiedzi Orygenesa, w których opowiada się on za poznawalnością, lub niepoznawalnością Boga. Powyższy tekst jednak, jasno ukazuje jego stanowisko w tej kwestii. Tak, Bóg jest poznawalny dzięki Mocy, którą jest Jego Syn. To On przecież, jak zauważa w innym miejscu Adamancjusz, rodzi się z Ojca niczym blask ze światłości (sicut splendor generatur ex luce $)^{126}$. Blask, czy też promienie, wskazują - wedle powyższej metafory - na źródło światła, którym jest słońce; ono jednak pozostaje oślepiające dla ludzkich oczu. Podobnie jest z Mocą i istotą Boga. Ta pierwsza jest rozpoznawalna przez ludzki umysł na podstawie piękna stworzenia i wskazuje na istnienie tej drugiej. Ta druga jednak, transcenduje możliwości poznawcze ludzkiego rozumu.

ukrytą w nich prawdę. Ponadto, uczył on nie tylko dokładnie badać i analizować każde twierdzenie, lecz nie pozwalał zatrzymywać się przy jednej tylko szkole filozoficznej, zob. Gregorius Thaumaturgus, In Origenem oratio panegyrica 7, 102-105; 14, 171-172. Taką właśnie metodę badawczą obserwujemy w wyżej cytowanych tekstach, jak i w tych, które będziemy omawiać poniżej, por. Origenes, Contra Celsum VI 62.

${ }^{124}$ Por. Origenes, De principiis I 1, 7; tenże, Contra Celsum VII 38.

${ }^{125}$ Tenże, De principiis I 1, 5-6, SCh 252, 98-100, thum. Kalinkowski, s. 61-62.

${ }^{126}$ Por. tamże I 2, 4, SCh 252, 118. 
Można wszakże postawić zarzut, iż powyższy tekst mówi jedynie o niepoznawalności Boga drogą naturalnego rozumu. W Piśmie Świętym jest jednak mowa o poznaniu Boga przez łaskę, która doprowadza do całej prawdy. Sam Orygenes wielokrotnie odwołuje się do danych skrypturystycznych, które mówią o nadprzyrodzonym poznaniu Boga ${ }^{127}$. Mało tego, proces poznawania Boga i Jego tajemnic jest - według Adamancjusza - drogą do doskonałości chrześcijańskiej lub też drogą do upodobnienia się do Boga ${ }^{128}$. Wspomina przy tej okazji, że doskonali chrześcijanie, zgodnie z Pismem, będą oglądać Boga w przyszłym świecie, tzn. po śmierci ${ }^{129}$. Nigdzie jednak nie stwierdza, iż owa eschatologiczna kontemplacja będzie polegała na doskonałym i zupełnym uchwyceniu istoty Boga. Wieloznaczność jego wypowiedzi, która wprowadza w zakłopotanie wielu komentatorów myśli Orygenesa, wynika zapewne z wieloznaczności czasownika: „znać”. O tej wieloznaczności wspomina również sam autor:

„Powiada Celsus, że «Bóg nie posiada niczego, co znamy», nie wyjaśnia jednak, «co znamy». Jeśli ma na myśli członki ciała, to zgadzamy się z nim całkowicie, rozumiejąc, że «to, co znamy» oznacza rzeczy cielesne w pospolitym znaczeniu tego słowa. Jeżeli zrozumiemy zwrot «to, co znamy» w sensie ogólnym, to stwierdzimy, że znamy wiele cech Boga: Bóg posiada bowiem cnotę, szczęście i boskość. Jeśli natomiast pojmujemy «to, co znamy» we wznioślejszym sensie, wszakże wszystko, co znamy, nie dorównuje Bogu, nic dziwnego, że i my stwierdzimy, iż Bóg nie posiada niczego, co znamy. To, co dotyczy Boga transcenduje bowiem wszystko to, co poznaje natura, nie tylko człowieka, ale także natura bytów, które ją przewyższają"130.

Do cech Boga, które znamy, a które lakonicznie zostały tu wyliczone, Orygenes mógłby dodać jeszcze wiele innych, które sam analizuje na kartach swoich pism, a które są danymi Objawienia. Wszystkie one mówią coś o naturze Boga. Jeśli jednak weźmiemy pod uwagę ontologiczną transcendencję natury Boskiej względem natury stworzonej, to należy stwierdzić, iż wszystko to, co, nawet poprawnie, człowiek myśli o Bogu, jest o wiele niższe, niż to, czym On

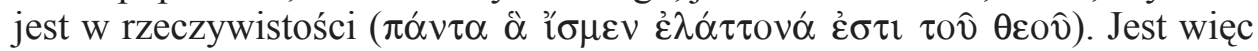
prawdą, na przykład, że Bóg jest niezłożony, niewidzialny i niematerialny, i że

${ }^{127}$ Por. tenże, Commentarii in Joannem XIII 24, 146; tenże, De principiis I 3, 4; tenże, Commentarii in Epistulam ad Romanos 3, 8; tenże, Contra Celsum VII 44.

${ }^{128}$ Por. tenże, De principiis III 6, 1. Szerzej na temat drogi poznania i upodobnienia się człowieka do Boga zob. H. Crouzel, Origène et la ,,connaissance mystique”, Bruges - Paris 1961; tenże, Orygenes, Kraków 2004, 137-175; M. Szram, Chrystus - Mąrość Boża wedtug Orygenesa, Lublin 1997, 175-248; G. Lettieri, Progresso, w: Origene. Dizionario. La cultura, il pensiero, le opere, a cura di A. Monaci Castagno, Roma 2000, 379-392.

${ }^{129}$ Por. Origenes, Commentarii in Joannem I 16, 91-93; I 43, 305-306; tenże, Commentarii in Epistulam ad Romanos 1, 16; tenże, De principiis IV 4, 10.

${ }^{130}$ Tenże, Contra Celsum VI 62, SCh 147, 334, tłum. Kalinkowski, s. 327 (thum. poprawione przez Autora). 
jest Rozumem; jednakże jest też prawdą, że Bóg jest „czymś” przewyższają-


pojmuje rozumność, czy istnienie, ma się nijak do tego, jak myśli i jak istnieje Bóg. Dlatego też Adamancjusz nie uważa za niedorzeczne stwierdzenie, iż tak naprawdę w Bogu nie ma żadnej z tych rzeczy, które zna, czyli ogarnia swym

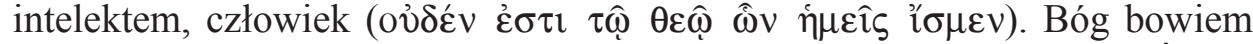

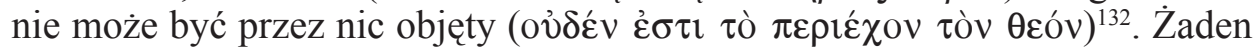
byt stworzony, czy to człowiek, czy stojący wyżej od niego anioł, z natury

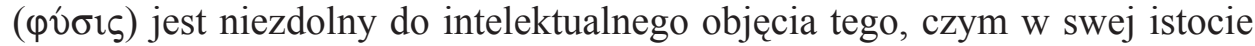
jest Bóg. W podobny, zniuansowany sposób, Orygenes podchodzi do zagadnienia nazywalności i definiowalności Boga. Zgadza się on, a zarazem nie zgadza, z twierdzeniem, iż „Boga można określić słowami”. Nie zgadza się, gdyż - jak wyjaśnia - uchwycenie istoty każdej rzeczy jest niezmiernie trudne, a niekiedy wręcz niemożliwe. Tym bardziej odnosi się to do istoty Boga. Zgadza się jednak Adamancjusz z twierdzeniem, iż można zdefiniować pewne przymioty Boga ,po to, aby pouczyć słuchacza i spowodować, ażeby dowie-

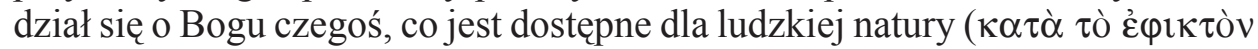

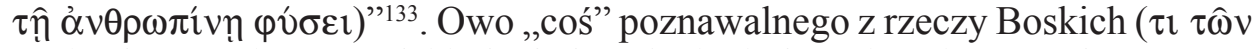
$\pi \varepsilon \rho i \alpha$ $\tau 0 \hat{)}$, nie prowadzi jednak do pełnej wiedzy o istocie Boga, która przewyższa wszelki rozum i wszelką wiedzę ${ }^{134}$.

Orygenes uzależnia więc swą odpowiedź na pytanie o poznawalność Boga, od odpowiedzi na pytanie, o znaczenie terminu ,znać” (oî́ $\alpha$ ). Jego rozróżnienia wcale nie zaprzeczają temu, co w innych miejscach pisze np. o eschatologicznym poznaniu tajemnic Boga, które Pismo nazywa oglądaniem Boga

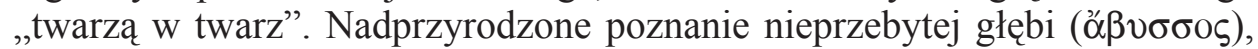
którą jest Bóg, i którą w jakiś sposób odsłania Syn ${ }^{135}$, nie oznacza wszakże intelektualnego objęcia całej głębi, która zawsze pozostaje nieogarniona ${ }^{136}$.

${ }^{131}$ Por. tamże VII 38, SCh 150, 100.

${ }^{132}$ Por. tamże VII 34, SCh 150, 90. Zob. także inne teksty, cytowane wyżej, w których Orygenes stwierdza, iż Bóg jest ogarniającym wszystko, lecz przez nic nieogarnionym.

${ }^{133}$ Tamże VI 65, SCh 147, 342, thum. własne.

${ }^{134}$ Por. tamże VII 45-46, SCh 150, 122, tłum. Kalinkowski, s. 368, gdzie Orygenes, przytacza-

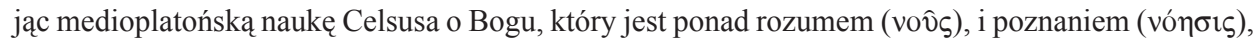
i wiedzą ( $\dot{\imath} \tau \imath \tau \eta \dot{\mu} \mu)$, stwierdza, iż nie ma zamiaru ,polemizować ze słusznymi stwierdzeniami, choćby autorami ich byli wrogowie naszej wiary".

${ }^{135}$ Por. tamże VI 17, SCh 147, 220-222.

${ }^{136}$ Por. tenże, De principiis IV 3, 14, ed. H. Crouzel - M. Simonetti, SCh 268, Paris 1980, $392-$ 394, tłum. Kalinkowski, s. 365-366, gdzie Adamancjusz, komentując wypowiedź Pawła na temat „głębokości (ßó日os) bogactw, mądrości i wiedzy Boga” oraz o „niezbadanych wyrokach Boga i nieogarnionych drogach Jego” (por. Rz 11,33), stwierdza: „Nie powiedział przecież, że z trudnością można zbadać wyroki Boże, lecz że wcale nie można ich zbadać; nie powiedział, że z trudnością można ogarnąć Jego drogi, lecz że nie można ich ogarnąć. Choćby bowiem nie wiadomo jak bardzo się ktoś przykładał do badań i w usilnym staraniu czynił postępy, nawet wspomagany łaską Bożą i oświecony w umyśle, nie zdoła dotrzeć do doskonałego celu badanych spraw. I żaden stworzony umysł nie może pojąć w żaden sposób, lecz gdy znajdzie cokolwiek z tego, czego szuka, widzi dal- 
Z transcendencji ontologicznej Boga, o której wyżej pisaliśmy, wynika więc Jego transcendencja epistemologiczna. Jedna i druga jest związana z Platońską metaforą słońca, którą jednak, jak to staraliśmy się pokazać, Orygenes modyfikuje, wyprowadzając z niej brzemienne i inspirujące konkluzje dla trynitologii, chrystologii, ale także antropologii i epistemologii.

Platońska metafora słońca oddziaływała tak na teologię heterodoksyjną, którą przedstawiliśmy w niniejszym artykule na przykładzie różnych systemów gnostyckich, jak i na teologię ortodoksyjną w szczególności na aleksandryjską, w pierwszych trzech wiekach chrześcijaństwa. Była ona jednak na różne sposoby interpretowana i adaptowana do poszczególnych doktryn teologicznych i filozoficznych. Według Platona, niczym słońce, które wznosi się ponad ziemią i sprawia, iż byty ziemskie powstają i rozwijają się, tak idea

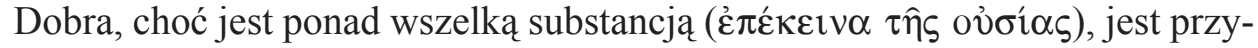
czyną istnienia tego, co realnie istnieje, a więc substancji, którymi są idee. Ponadto, tak jak słońce, które sprawia, iż to, co istnieje na ziemi staje się widzialne dla oczu, tak idea Dobra jest przyczyną poznawalności bytów inte-


Platona - może być przedmiotem nauki, którą jest filozofia.

Dla chrześcijan, owym transcendentnym względem wszelkich istniejących substancji bytem, który jest przyczyną istnienia tego, co istnieje, jest oczywiście Bóg Ojciec. Na tym etapie jednakże, nie kończy się dialog z platońską filozofią. Pierwszą ważną modyfikacją w stosunku do konkluzji, które z metafory słońca wyciagał Platon, jest zwrócenie przez chrześcijan uwagi na element promieni słonecznych, pominięty przez ateńskiego filozofa. Dla gnostyków owymi promieniami są eony, emanowane przez Pierwszą Zasadę rzeczywistości - Bythosa; dla Klemensa i Orygenesa jest nimi Syn Boży, czyli Moc i Mądrość Boga, który, choć jeden, na różne sposoby działa i objawia się w świecie stworzonym. Tak dla pierwszych, jak i dla drugich, Bóg, nazywany Dobrem, pozostaje transcendentny względem rozlicznych dóbr, które od Niego pochodza, i które w tym najwyższym Dobru na różne sposoby uczestniczą. Owa transcendencja ontologiczna Boga jest jednak inaczej rozumiana przez gnostyków, a inaczej przez Klemensa i Orygenesa. Oto bowiem, podczas gdy eony, choć współistotne boskiej naturze, w miarę oddalania się od Praprzyczyny, ulegają pewnej degradacji, a z pewnością coraz mniej wiedzą o źródle, z którego wyszły, tak Syn Boży, w teologii ortodoksyjnej, pozostaje

sze problemy, które trzeba zbadać; a jeśli i te rozstrzygnie, ujrzy znowu jeszcze więcej zagadnień, które powinny zostać zbadane". Z wypowiedzi tej jasno wynika, iż Bóg jest poznawalny drogą ludzkiego rozumu i przy udziale nadprzyrodzonej łaski, lecz proces owego poznawania Boga nigdy nie będzie miał końca, co oznacza, iż istota Boża nigdy nie będzie do końca poznana i ogarniona przez ludzki stworzony intelekt. 
zawsze tą samą Mocą i Mądrością Boga, nawet wówczas, gdy działa na ziemi, jako wcielony Logos. Będąc zrodzony z Boga, ale i nigdy się od Niego nie odłączając, zna Ojca i działa wedle tego, co widzi u Ojca. Pewna transcendencja Ojca względem Syna zostaje jednak podkreślona tak przez Klemensa, jak i przez Orygenesa. Nie polega ona jednak na stwierdzeniu, iż natura, czy moc Ojca różnią się od natury i mocy Syna, lecz na tym, iż Ten pierwszy jest absolutną Przyczyną wszystkiego - wszelkiej istniejącej substancji: zrodzonej i stworzonej. To On ogarnia wszystko, a sam przez nic nie jest ogarniony (jest $\pi \varepsilon p t \varepsilon ́ \chi \omega \nu$ ov̉ $\pi \varepsilon p \iota \varepsilon \chi o ́ \mu \varepsilon v o \varsigma)$. Jest również Przyczyną ontologiczną Przyczyny stwórczej, którą jest Syn. Wraz z Platonem, Klemens i Orygenes moga

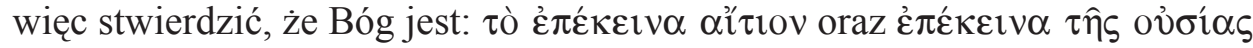
(,ponad przyczyną" i ,ponad substancją"). Z tymi ostatnimi wypowiedziami zgodziliby się i gnostycy, choć, jak wspomnieliśmy wyżej, transcendencja Pierwszej Zasady względem eonów, jest o wiele większa (gdyż zakładają oni pewną degradację świata duchowego poprzez kolejne emanacje) niż ma to miejsce w przypadku teologii ortodoksyjnej. Ta ostatnia podkreśla jedynie relację między Boskimi hipostazami, a więc wskazuje na logiczne pochodzenie jednej od drugiej, bez umniejszania mocy żadnej z nich.

Zarówno gnostycy, jak Klemens i Orygenes, wykorzystują również epistemologiczną interpretację metafory słońca, której dokonał Platon. Jednakże i w tym względzie polemizują z filozofem ateńskim. Tak jedni, jak i drudzy zgadzają się więc z Platonem stwierdzając, że Bóg jest przyczyną poznawalności tego, co istnieje realnie, a więc świata bytów niecielesnych i boskich. Jest jednak poznawalny za sprawą eonów, bądź Syna, którzy w obu przypadkach porównywani są do światła mającego swe źródło w Ojcu. Zarówno gnostycy, jak Klemens i Orygenes nie zgadzają się natomiast z filozofem ateńskim w kwestii poznawalności istoty Pierwszej Zasady. Według Platona bowiem, o czym pisaliśmy w pierwszym punkcie tego tekstu, idea Dobra jest

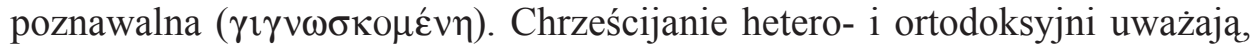
że transcendentny Bóg, oświeca wprawdzie ludzki intelekt w sprawach tego, co boskie, lecz sam w sobie jest On światłością oślepiająca. Poznawalne jest więc według nich to, co od Niego pochodzi, natomiast nie samo źródło światła. Podobnie więc jak ludzkie oko nie jest w stanie patrzeć na samo słońce, choć dzięki jego promieniom widzi rzeczy materialne, tak też naturalne możliwości ludzkiego rozumu nie są w stanie pojąć tego, czym w swej istocie jest Bóg, choć rozpoznają Jego Moc i dostrzegają Ją w dziełach, które przez Nią powstały. W tej ostatniej kwestii jednak, również zachodzą pewne różnice między tezami gnostyków a teologią Klemensa i Orygenesa. Ci pierwsi głoszą absolutną niepoznawalność Pierwszej Przyczyny, ci drudzy sprawę niuansują. Według gnostyków, nawet same eony nie znają w zupełności Ojca, a niekiedy ich ignorancja utrzymuje $\mathrm{w}$ nieświadomości również byty niższe od nich. Wprawdzie o Bogu mogą mieć wiedzę nieliczni pneumatycy, którzy posiadają w sobie współistotny boskiej rzeczywistości element świata duchowego, lecz 
i oni nie posiadają całkowitej wiedzy o transcendentnej Prazasadzie. I nawet na końcu czasów, powróca, nie do Ojca, lecz do miejsca, które zostało im wyznaczone w hierarchicznym świecie Pleromy. Według Klemensa i Orygenesa natomiast, Ojciec jest poznawalny dzięki Synowi, Mocy i Mądrości Bożej stwarzającej, rządzącej i obecnej w świecie, a jeszcze bardziej staje się On poznawalny poprzez Wcielenie Syna. Ponieważ Syn jest substancjalnie złączony z Ojcem, i ponieważ Syn zna Ojca, objawia wszystkim, którzy w Niego wierza, prawdę o Bogu transcendentnym. Należy jednak zaznaczyć, iż Klemens i Orygenes, nie odrzucając danych zawartych w Objawieniu i zgadzając się $\mathrm{z}$ teza, że zbawienie polega na poznaniu Boga, przyjmują koncept epistemologicznej transcendencji Boga, która jest związana z Jego transcendencją ontologiczna. Skoro bowiem Bóg w swojej istocie nie może być przez nic ogarniony, nie może też być zamknięty w żadnej definicji. Istota Boga wymyka się więc wszelkim fizycznym i metafizycznym kategoriom. Klemens stwierdza nawet wprost, iż Bóg nie może być przedmiotem żadnej nauki. Orygenes natomiast, choć jak widzieliśmy, sprawę niuansuje, ostatecznie dochodzi do podobnej konkluzji. Według niego, poznanie per analogiam, którym posługuje się człowiek w odniesieniu do istoty Boga, wskazuje na większe niepodobieństwo, aniżeli podobieństwo, rzeczywistości porównywanych z przedmiotem porównania. A skoro tak, to prawdziwe jest według niego zdanie, iż człowiek nie wie o Bogu „nic” (oủdév). Bóg w swej istocie bowiem, co Orygenes może

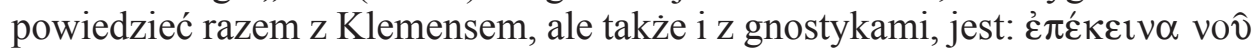

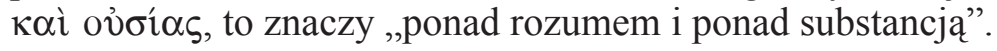

\author{
THE METAMORPHOSIS OF THE PLATONIC \\ "METAPHOR OF THE SUN" (RESPUBLICA 509B) \\ IN HETERODOX AND ORTHODOX THEOLOGY (I-III CENTURIES): \\ GNOSTICISM, CLEMENT OF ALEXANDRIA AND ORIGEN
}

\title{
(Summary)
}

The metaphor of the sun, in which Plato (Republic 509b) compares the idea of the Good to the sun that dwells above the earth yet affects the phenomena occurring on it, was an inspiration for both heretical and orthodox theology in the first Christian centuries. The Gnostics, Clement of Alexandria and Origen all believed that God, like the Platonic idea of the Good, is radically transcendent in relation to the world, but at the same time is the cause of everything that exists in it. Unlike Plato, who believed that the idea of the Good is knowable and can be the subject of science, the Christian theologians of the first centuries believed that God was like a blinding light. This means that God, according to them, though intelligible, is unknowable in His essence. Therefore, God cannot be the subject of science. Another modification of the Platonic metaphor was the introduction of the element of sunlight, to which the philosopher from Athens did not refer. 
For the Gnostics, the rays of the sun were "eons" - spiritual beings that existed in the space between the first principle of all things and the material world. For Clement and Origen, the light that comes from the sun was the Son - the power and wisdom of God. In contrast to the Gnostics, who believed in the progressive degradation of the spiritual world through successive emanations, the Alexandrian Fathers believed that the Son possessed all the knowledge of God and therefore revealed to man the true God. Yet the revelation of God by the Son, and even the grace that assists human beings in the process of learning about God, do not give man complete knowledge of the essence of God. Thus the Gnostics, Clement and Origen, despite some doctrinal differences, all accepted the concept of the radical transcendence of God on the ontological and epistemological levels.

Key words: Idea of the Good, transcendence of God, platonism, gnosticism, Clement of Alexandria, Origen, the influence of Greek philosophy on Christianity.

Slowa kluczowe: Idea Dobra, transcendencja Boga, platonizm, gnostycyzm, Klemens Aleksandryjski, Orygenes, wpływ greckiej filozofii na chrześcijaństwo.

\section{BIBLIOGRAFIA}

\section{Źródła}

Clemens Alexandrinus, Eclogae propheticae, ed. L. Früchtel, GCS 17, Leipzig 1909, 137-155.

Clemens Alexandrinus, Excerpta ex Theodoto, ed. L. Früchtel, GCS 17, Berlin 1909, 105-133.

Clemens Alexandrinus, Paedagogus, ed. O. Stählin, GCS 12, Leipzig 1905, 87-292.

Clemens Alexandrinus, Stromata, ed. L. Früchtel, I-VI, GCS 15, Leipzig 1906, VII-VIII, GCS 17, Leipzig 1909, 3-102, tłum. J. Niemirska-Pliszczyńska: Klemens Aleksandryjski, Kobierce zapisków filozoficznych dotyczacych prawdziwej wiedzy, I-II, Warszawa 1994.

Epiphanius Constantiensis, Panarion, ed. K. Holl, 1-33, GCS 25, Leipzig 1915, 153-464, thum. M. Gilski: Epifaniusz z Salaminy, Panarion. Herezje 1-33. Tekst grecki i polski, Kraków 2015.

Gregorius Thaumaturgus, In Origenem oratio panegyrica, ed. H. Crouzel, SCh 148, Paris 1969, 94-182.

Hippolytus Romanus, Refutatio omnium haeresium, ed. M. Marcovich, PTS 25, Berlin - New York 1986.

IRENAeus, Adversus haereses, ed. A. Rousseau - L. Doutreleau, Livre I, SCh 264, Paris 1979, tłum. W. Myszor: Ireneusz z Lyonu i gnostycy, Zdemaskowanie i odparcie fatszywej gnozy. Ttumaczenie: Adversus haereses. Księga I i II, SACh NS 17, Katowice 2016.

Origenes, Commentarii in Epistulam ad Romanos, ed. C.P. Hammond Bammel - M. Fédou - L. Brésard, I-II, SCh 532, Paris 2009, III-V, SCh 539, Paris 2010, VI-VIII, SCh 543, Paris 2011, IX-X, SCh 555, Paris 2012, tłum. S. Kalinkowski: Orygenes, Komentarz do Listu św. Pawła do Rzymian, PSP 57, cz. 1-2, Warszawa 1994.

Origenes, Commentarii in Joannem, ed. C. Blanc, I-V, SCh 120, Paris 1966, VI, SCh 157, Paris 1970, XIII, SCh 222, Paris 1975, XIX-XX, SCh 290, Paris 1982, XVIII-XXXII, 
SCh 385, Paris 1992, tłum. S. Kalinkowski: Orygenes, Komentarz do Ewangelii wedtug św. Jana, ŹMT 27, Kraków 2003.

Origenes, Contra Celsum, ed. M. Borret, Livres I-II, SCh 132, Paris 1967, Livres III-IV,

SCh 136, Paris 1968, Livres V-VI, SCh 147, Paris 1969, Livres VII-VIII, SCh 150,

Paris 1969, thum. S. Kalinkowski: Orygenes, Przeciw Celsusowi, Warszawa 1986.

Origenes, De oratione, ed. P. Koetschau, GCS 3, Leipzig 1899, 295-403.

Origenes, De principiis, ed. H. Crouzel - M. Simonetti, I-II, SCh 252, Paris 1978, III-IV,

SCh 268, Paris 1980, tłum. S. Kalinkowski: Orygenes, O zasadach, ŹMT 1, Kraków 1996.

Philo Alexandrinus, Opera quae supersunt, ed. L. Cohn - P. Wendland - S. Peiter, I-VI, Berlin 1896-1915.

Plato, Phaedo, ed. R.D. Archer-Hind, London 1894.

Plato, Phaedrus, ed. W.H. Thompson, London 1868.

Plato, Respublica, ed. J. Adam, Cambridge 1900.

Plato, Timaeus, ed. R.D. Archer-Hind, London 1888.

Stoicorum Veterum Fragmenta, ed. H. von Arnim, I-III, Leipzig 1903-1905.

Tertullianus, De praescriptione haereticorum, ed. R.F. Refoulé, SCh 46, Paris 1957, tłum. E. Stanula, w: Kwintus Septymiusz Florens Tertulian, Wybór pism, PSP 5, Warszawa 1970, 40-78.

Testi gnostici in lingua greca e latina, a cura di M. Simonetti, Milano 2005.

Tractatus Tripartitus, ed. H.W. Attridge, w: Nag Hammadi Codex I (The Jung Codex), NHS 22, Leiden 1985, 192-337, thum. W. Myszor: Tractatus Tripartitus, w: Biblioteka z Nag Hammadi. Kodeksy I i II, SACh SN 7, Katowice 2008, 89-166.

\section{Opracowania}

Chiapparini G., Valentino gnostico e platonismo. Il valentinianesimo della „, Grande Notizia” di Ireneo di Lione: Fra esegesi gnostica e filosofia medioplatonica, Milano 2012.

Corsini E., Introduzione, w: Origene, Commento al Vangelo di Giovanni, a cura di E. Corsini, Torino 1995, 9-102.

Crouzel H., Origène et la „,connaissance mystique”, Bruges - Paris 1961.

Crouzel H., Orygenes, Kraków 2004.

Daniélou J., Message évangélique et culture hellénistique aux II et III siècles, Paris 1961.

Daniélou J., Orignène, Paris 1948.

Edwards M.J., Origen Against Plato, Oxford 2002.

GAISER K., Platons ungeschriebene Lehre, Stuttgart 1963.

HäGg H.F., Clement of Alexandria and the Beginnings of Christian Apophaticism, Oxford 2006.

Harnack von A., Das Wesen des Christentums, Leipzig 1900.

HARNACK VON A., Lehrbuch der Dogmengeschichte, vol. 1-3, Freiburg 1886-1890.

Lilla S.R.C., Clement of Alexandria. A Study in Christian Platonism and Gnosticism, Eugene 2005.

Moreschini C., Storia del pensiero cristiano tardo-antico, Milano 2013.

Mrugalski D., Il Dio trascendente nella filosofia alessandrina giudaica e cristiana. Filone e Clemente, Roma 2013.

Origene. Dizionario. La cultura, il pensiero, le opere, a cura di A. Monaci Castagno, Roma 2000.

Pietras H., Pojęcie Bożej substancji w poczatkach Kościoła, w: Metafizyka i teologia, red. R.J. Woźniak, Myśl Teologiczna 62, Kraków 2008, 122-140. 
Platon. Nowa interpretacja. Materiały z sympozjum: KUL 30 listopada - 2 grudnia 1992 r., red. A. Kijewska - E.I. Zieliński, Lublin 1993.

Reale G., Historia filozofii starożytnej, II: Platon i Arystoteles, thum. E.I. Zieliński, Lublin 2005.

Reale G., Per una nuova interpretazione di Platone alla luce delle „,dottrine non scritte”, Milano 2010.

Simonetti M., Między dosłownościq a alegoriq. Przyczynek do historii egzegezy patrystycznej, tłum. T. Skibiński, Myśl Teologiczna 26, Kraków 2000.

Simonetti M., Sulla teologia trinitaria di Origene, w: tenże, Studi sulla cristologia del II e III secolo, SEA 44, Roma 1993, 109-143.

Szlezák T.A., Czytanie Platona, thum. P. Domański, Warszawa 1997.

SzlezÁK T.A., O nowej interpretacji platońskich dialogów, tłum. P. Domański, Kęty 2005.

Szram M., Chrystus - Madrość Boża wedtug Orygenesa, Lublin 1997.

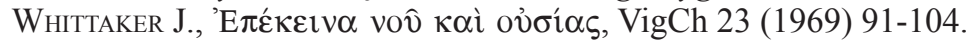

